\title{
Gas hydrate on the northern Cascadia margin: regional geophysics and structural framework ${ }^{1}$
}

\author{
M. Riedel, ${ }^{2}$ E.C. Willoughby, ${ }^{3}$ M.A. Chen, ${ }^{3}$ T. He, ${ }^{4}$ I. Novosel, ${ }^{5}$ K. Schwalenberg, ${ }^{6}$ \\ R.D. Hyndman, ${ }^{3}$ G.D. Spence, ${ }^{4}$ N.R. Chapman, ${ }^{4}$ and R.N. Edwards ${ }^{7}$
}

\section{Chapter contents}

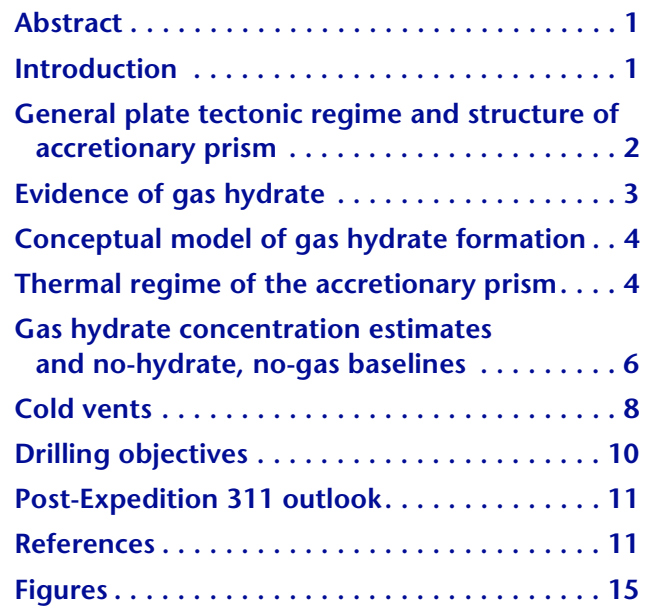

${ }^{1}$ Riedel, M., Willoughby, E.C., Chen, M.A., He, T., Novosel, I., Schwalenberg, K., Hyndman, R.D., Spence, G.D., Chapman, N.R., and Edwards, R.N., 2006. Gas hydrate on the northern Cascadia margin: regional geophysics and structural framework. In Riedel, M., Collett, T.S., Malone, M.J., and the Expedition 311 Scientists. Proc. IODP, 311: Washington, DC (Integrated Ocean Drilling Program Management International, Inc.). doi:10.2204/iodp.proc.311.109.2006

'Expedition 311 Scientists' addresses. Correspondence author: mriedel@eps.mcgill.ca ${ }^{3}$ Pacific Geoscience Centre, Geological Survey of Canada, 9860 West Saanich Road, PO Box 6000, Sidney BC VSL 4B2, Canada.

${ }^{4}$ Earth and Ocean Sciences, University of Victoria, Victoria BC V8W 2Y2, Canada.

${ }^{5}$ Hydrocarbon Systems-EP Solutions, Shell International Exploration and Production, Inc., 200 North Dairy Ashford Street, Houston TX 77079, USA. ${ }^{6}$ Federal Institute for Geosciences and Natural Resources (BGR), Geozentrum Hannover, Hannover D-30655, Germany.

${ }^{7}$ Department of Physics, University of Toronto, Toronto ON M5S 1A7, Canada.

\section{Abstract}

Integrated Ocean Drilling Program Expedition 311 is based on extensive site survey data and historic research at the northern Cascadia margin since 1985 . This research includes various regional geophysical surveys using a broad spectrum of seismic techniques, coring and logging by the Ocean Drilling Program Leg 146 , heat flow measurements, shallow piston coring, and bottom video observations across a cold-vent field, as well as novel controlled-source electromagnetic and seafloor compliance surveying techniques. The wealth of data available allowed construction of structural cross-sections of the margin, development of models for the formation of gas hydrate in an accretionary prism, and estimation of gas hydrate and free gas concentrations. Expedition 311 established for the first time a transect of drill sites across the northern Cascadia margin to study the evolution of gas hydrate formation over the entire gas hydrate stability field of the accretionary complex. This paper reviews the tectonic framework at the northern Cascadia margin and summarizes the scientific studies that led to the drilling objectives of Expedition 311 Cascadia gas hydrate.

\section{Introduction}

The northern Cascadia margin offshore Vancouver Island has been the focus of many marine geological and geophysical studies over the past two decades, including Ocean Drilling Program (ODP) Leg 146 (Westbrook, Carson, Musgrave, et al., 1994). Adjacent onshore studies of the LITHOPROBE program (e.g., Clowes et al., 1987a, 1987b), as well as large-scale seismic reflection profiling along the margin allowed the construction of continuous onshore-offshore structural cross sections (e.g., Hyndman, 1995). These earlier undertakings were continued in the forearc by the Seismic Hazard Investigations in Puget Sound (SHIPS) project in 1998 (Fisher et al., 1999), which resulted in new multichannel seismic (MCS) reflection lines and higher resolution structural maps of the forearc part of the subduction zone, including largescale seismic tomography studies (e.g., Ramachandran et al., 2004, 2005).

More recent offshore detailed seismic reflection surveys focused on gas hydrate studies providing supporting data for the Cascadia Integrated Ocean Drilling Program (IODP) drilling objectives such 
as determining the origin of the bottom-simulating reflector (BSR), the role of sediment consolidation and fluid expulsion in regional gas hydrate formation, and the significance of newly found cold vents in the overall fluid budget of the accretionary prism.

This paper summarizes many of the previous findings, describes the structural background of the northern Cascadia margin, and introduces the area of detailed investigation along the transect of drillsites established during IODP Expedition 311.

\section{General plate tectonic regime and structure of accretionary prism}

Comprehensive summaries of the regional geological framework and tectonics of the northern Cascadia margin were previously given by Hyndman et al. (1994) and Hyndman (1995). Extensive reference lists therein provide further detailed information. In this paper we describe only the most significant elements as they relate to the Expedition 311 objectives.

The Juan de Fuca subduction zone, with its large accretionary prism, is part of the mainly right-lateral transform boundary of the continental margin of western North America, which includes the San Andreas fault system extending from the Gulf of California to Cape Mendocino off northern California and the Queen Charlotte fault system extending from just north of Vancouver Island to the Aleutian Trench off Alaska (Fig. F1). The present Juan de Fuca plate configuration had its origin in a major reorganization of the northeast Pacific plate regime in the Eocene, 43 m.y. ago. Since this time, convergence has been continuous and approximately orthogonal to the coast along the northern portion of the Cascadia margin. The present rate of convergence is $\sim 46$ $\mathrm{mm} / \mathrm{y}$ off southern Vancouver Island (Riddihough, 1984). Two narrow exotic terranes were emplaced against the Cascadia margin at $\sim 43 \mathrm{Ma}$ : the Eocene marine volcanic Crescent Terrane and the Mesozoic mainly marine sedimentary Pacific Rim Terrane (Fig. F2). The Crescent Terrane provides the landwarddipping backstop to the accretionary prism that has accumulated since the Eocene (e.g., Davis and Hyndman, 1989; Hyndman et al., 1990). The Tofino Basin, containing as much as $4 \mathrm{~km}$ of gently deformed Eocene and Holocene sediments, was deposited over the accretionary wedge and the two accreted terranes beneath the continental shelf of southern Vancouver Island (e.g., Tiffin et al., 1972; MacLeod et al., 1977; Dehler and Clowes, 1992). The results of petroleum exploration wells drilled into the shelf in the 1960s were described by Shouldice $(1971,1973)$.

In 1985, widely spaced marine MCS lines were acquired across the continental shelf and slope off Vancouver Island as part of the Frontier Geoscience program of the Geological Survey of Canada. As part of the site survey for Leg 146, additional MCS data were acquired in 1989, out of which Lines 89-07, 89$08,89-10$, and $89-11$ have direct relevance to the drilling transect of Expedition 311 (Fig. F3). Site survey seismic data especially acquired for Expedition 311 and a review of the older seismic data are given in the report by Scherwath et al. (this volume).

The incoming 2.3-3.0 km thick sediment section on oceanic crust of the Juan de Fuca plate consists of an upper $1.5-2 \mathrm{~km}$ of acoustically layered turbidite sediment interval overlying a section of more seismically transparent sediments, interpreted to be prePleistocene hemipelagic sediments deposited on the flanks of the Juan de Fuca Ridge (e.g., Hayes and Ewing, 1970; Davis and Hyndman, 1989). No significant bathymetric trench is present adjacent to the Cascadia accretionary prism. At the deformation front, thrusts reach close to the top of the oceanic crust and the sediments of the Cascadia Basin are almost completely scraped off the downward-moving oceanic crust. The sediments are folded and faulted into anticlinal ridges that stand as high as $700 \mathrm{~m}$ above the adjacent seafloor. Individual ridges are typically $20-30 \mathrm{~km}$ in length, a few kilometers in width, and generally parallel to the margin. The internal structure of the ridges is continuous along strike, but their shape is usually asymmetric with the steep flank facing seaward (e.g., Davis and Hyndman, 1989; Rohr, 1987; Hyndman et al., 1994).

An important process in the development of accretionary prisms is load-induced tectonic consolidation and pore fluid expulsion. There is a progressive transformation, both with depth and landward, of the incoming high-porosity unconsolidated sediments into low-porosity sedimentary rock. The consolidation mainly involves loading-induced physical compaction and porosity loss. Deformation-induced changes in the grain-scale sediment structure, grain cementation processes, and chemical clay-mineral changes resulting from heating are also important. The primary data to define pore fluid expulsion associated with sediment prism accretion are seismic velocities from MCS data (e.g., Westbrook, 1991; Moore and Vrolijk, 1992; Yuan et al., 1994). Detailed velocity/porosity cross sections across the accretionary prism were constructed along seismic Lines 89-04 and 89-07 by Yuan et al. (1994). To a first order, the velocity changes are closely associated with porosity 
changes. For both Cascadia Basin and the accretionary prism, inferred porosity decreases approximately exponentially with depth, as expected for sediment loading consolidation in a relatively homogeneous section. Yuan et al. (1994) found that in areas where the prism has thickened substantially, the porosities are much higher at any given depth than beneath the Cascadia Basin. This landward porosity increase and underconsolidation are inferred to be a consequence of horizontal shortening and vertical stretching of the porosity-depth profile. Sediment elements do not increase in porosity; rather, they simply move to greater depths where the porosity would normally be lower. The tectonic thickening occurs faster than the loading and pore fluid expulsion can reestablish a normally consolidated depth section.

In summary, the sediment accretion process can be represented by a combination of two processes:

1. Bulk shortening and vertical thickening of the section and

2. Thrust faulting that emplaces high-porosity surface sediments at greater depth.

The subsequent process of reestablishing the porosity-depth profile by consolidation and fluid expulsion has large implication for the formation of gas hydrate in accretionary prisms, as outlined in greater detail below.

\section{Evidence of gas hydrate}

Data from Leg 146 indicates widespread gas hydrate on Canada's West Coast at the Northern Cascadia margin, as evidenced by BSRs in seismic reflection data and increased electrical resistivity compared to normal sediments in electromagnetic surveys, and gas hydrate has been sampled at and just below the seafloor by shallow piston coring (see Hyndman et al., 2001, and Spence et al., 2000a, for earlier summaries). Closely related geophysical data are also available for central Cascadia off Oregon from ODP Leg 204 (e.g., Tréhu, Bohrmann, Rack, Torres, et al., 2003, and references therein). After the first discovery of BSRs in MCS data in 1985, the area offshore central Vancouver Island (Fig. F3) has had many interdisciplinary gas hydrate studies. The initial work focused on mapping the regional distribution of the BSRs and determining the associated regional concentrations of underlying free gas or overlying gas hydrate (e.g., Hyndman and Spence, 1992; Yuan et al., 1996). The more recent studies focused on coldvent structures that in some cases result in high-concentration gas hydrate near the seafloor, especially a vent field on the mid-continental slope near ODP Site 889/890 (Riedel et al., 2002, 2006).
A wide variety of seismic surveys have been used to map and characterize the gas hydrate and underlying free gas on the Northern Cascadia margin. The seismic systems had principal frequencies from 20 to $650 \mathrm{~Hz}$ and included conventional MCS survey lines, three-dimensional (3-D) higher resolution MCS surveys, the high-resolution deep-tow acoustics-geophysics system (DTAGS) system that is towed near the seafloor, detailed close-line-spacing single-channel reflection mapping, and studies using ocean bottom seismometers (OBSs). Additional high-resolution 3.5 and $12 \mathrm{kHz}$ subbottom profiling, $12 \mathrm{kHz}$ swath SeaMARC-II acoustic imaging, and piston coring provided data from the upper 1-50 $\mathrm{m}$ beneath the seafloor.

The regional distribution of the BSR, which is characteristic of many marine gas hydrate areas, has been well mapped seismically. A BSR occurs beneath much of the middle continental slope off Vancouver Island but is completely absent in the deep Cascadia Basin. The BSR approaches the seafloor on the upper slope and gas hydrate is not stable on the continental shelf for water depths less than $\sim 600 \mathrm{~m}$ in this area. The surveys and analyses of the seismic data include

- Estimating the BSR reflection coefficient (Spence et al., 1991a, 1991b, 1995; Hyndman et al., 1994; Yuan et al., 1994),

- Modeling the BSR reflection waveform (Hyndman and Spence, 1992; Fink and Spence, 1999),

- Determining and modeling the frequency dependence of the BSR (Chapman et al., 2002),

- Determining detailed interval velocity-depth profiles (Yuan et al., 1996),

- Determining and modeling the amplitude versus offset (AVO) behavior of the BSR (Hyndman and Spence, 1992; Yuan et al., 1999; Riedel et al., 2002)

- Determining the full waveform inversion (FWI) of the seismic data for velocity-depth profiles (Singh et al., 1993; Singh and Minshull, 1994; Yuan et al., 1996, 1999), and

- Determining geological associations of gas hydrate BSRs (Hyndman and Davis, 1992; Fink and Spence, 1999; Yuan et al., 1999; Mi, 1998; Ganguly et al., 2000).

We have also deployed several other important geophysical surveying techniques to map the gas hydrate distribution and estimate hydrate concentrations in the vicinity of Site 889. An important new technique for mapping subseafloor gas hydrate concentrations is the controlled-source electromagnetic (CSEM) profiling system developed at the University of Toronto, Canada (Edwards, 1997; Yuan and Edwards, 2001). Excellent agreement has been obtained 
in the resistivity and depth between the ODP downhole resistivity logs and the electrical profiling system data (Yuan and Edwards, 2001). The latest deployments of the CSEM system were focused on the area of the cold vents and yielded very high electrical resistivity over the near-seafloor gas hydrate concentrations (Schwalenberg et al., 2005; Willoughby et al., 2005; see discussion below). A second new technique for studying seafloor gas hydrate and associated free gas is seafloor compliance using the coherence between seafloor pressure variations induced by surface gravity and infragravity waves and the associated deformation of the seafloor (Willoughby and Edwards, 1997, 2000; Willoughby et al., 2005). The data are primarily sensitive to the shear modulus of the sediments in the upper few hundred meters below the seafloor. Cementing of sediments by gas hydrate substantially increases the shear modulus.

\section{Conceptual model of gas hydrate formation}

The formation of substantial amounts of gas hydrate requires large amounts of methane. Geochemical and isotope analyses have shown the methane to be mainly of biogenic origin on the Cascadia margin. Gas hydrate may be formed from biogenic methane that is generated locally at depths where pressure and temperature conditions are within the gas hydrate stability zone (GHSZ). However, there appears to be insufficient organic carbon in the Cascadia sediments in the section above the BSR to produce the estimated amounts of hydrate. Therefore, a model has been developed where the methane is generated over a great depth interval and gas hydrate is formed through removal of the methane from upward-moving pore fluids as they pass into the GHSZ (Hyndman and Davis, 1992) (Fig. F4). In this fluid expulsion model, the required biogenic methane may be generated throughout a thick sediment section extending well below the BSR. In its simplest form for regional gas hydrate, the upward fluid expulsion model predicts the highest concentration of gas hydrate just above the BSR, decreasing upward.

In the mid-slope region where the sediments are $\sim 5$ $\mathrm{km}$ thick, the rapid thickening of the sedimentary wedge results in sediment elements being moved to greater depths with little immediate porosity loss and associated velocity change. The sediments are therefore underconsolidated for their new depth, and high pore pressures are generated that are slowly dissipated through upward fluid expulsion (Hyndman et al., 1993). Fluid expulsion rates that reach $\sim 1$ $\mathrm{mm} / \mathrm{y}$ appear to be sufficient to carry enough meth- ane upward to the GHSZ to form as much as several tens of percent gas hydrate saturation. The second important process is that, subsequent to initial gas hydrate formation on the lower continental slope, the sediments are carried landward into the prism where there is shallower water depth and therefore pressure. As a result, the stability field must move upward because of pressure reduction from tectonic uplift and ongoing sediment deposition. The gas hydrate just above the BSR is therefore progressively moved out of the stability field and dissociated to free gas. The free gas in turn will migrate upward or be carried upward by the fluid expulsion to be reincorporated as gas hydrate above the newly reformed, shallower BSR (e.g., Paull et al., 1994). This progressive accumulation of methane just above the BSR results in the maximum regional concentration of gas hydrate being expected not far above the BSR (e.g., Zatsepina and Buffett, 1998; Xu and Ruppel, 1999). The thickness and concentration of the free gas layer are expected to depend upon the permeability of sediments to rising free gas and the rate of fluid expulsion that carries the gas upward. For northern Cascadia, the permeability and fluid expulsion rate appears sufficient, in that there is only a thin layer a few tens of meters thick of free gas with average concentration estimated to be $<1 \%$ (Desmons, 1996). In contrast, in the Blake Ridge area off eastern North America, the estimated gas concentrations are much higher $(\sim 5 \%)$ and much thicker $(\sim 100 \mathrm{~m})$ (e.g., Paull et al., 1996). In that region, the hydrate is in finer grained sediments with probably lower permeability, and upward fluid expulsion rates are much lower. The free gas produced by the upward-moving base of the gas hydrate stability field, therefore, will remain beneath the BSR for a much longer time.

\section{Thermal regime of the accretionary prism}

Thermal data provide one indicator of the upward fluid expulsion, which is thought to carry methane generated at depth into the GHSZ. The thermal regime also controls the depth to the base of the hydrate stability field and the BSR in the region. The geothermal gradient from downhole measurements at Site 889 was determined to be $54^{\circ} \mathrm{C} / \mathrm{km}$ (Westbrook, Carson, Musgrave et al., 1994). The pressuretemperature conditions at the BSR are $\sim 1^{\circ} \mathrm{C}$ cooler than expected from the theoretical gas hydrate stability for a seawater-methane mixture, but this discrepancy is within the general measurement uncertainty. The discrepancy is, however, larger if the pore water is significantly fresher than seawater. 
A regional compilation of heat flow data in the Juan de Fuca plate region was given by Hyndman (1983), and Davis et al. (1990), and they reported heat flow measurements across the Vancouver Island deformation front and lower continental slope. Additional heat-probe measurements in the area of Site 889 were conducted in 2000 along major seismic lines (Spence et al., 2000b; Riedel, 2001) and a cold-vent field with evidence of active fluid flow. Repeat measurements at Site 889 were conducted in 1992 (Hyndman et al., 1994) and at the most prominent cold vent in 2000 (H. Villinger, unpubl. data, 2000). The seismically determined depth to the BSR has been used to map the thermal regime of the continental slope by Hyndman et al. (1993) and Ganguly et al. (2000).

The large-scale subduction thermal regime across the margin has been modeled numerically (Hyndman and Wang, 1993; Wang et al., 1995). The model includes dependence on the age of the subducting plate, the plate convergence rate, the thickness of insulating sediments on the incoming oceanic crust, the angle profile of the subduction fault, and the thermal properties of the overlying accretionary prism and forearc crustal material (Fig. F2). The model also includes radioactive heat generation data from land sites and the continental shelf wells, with values ranging from 0.4 to $0.6 \mathrm{~mW} / \mathrm{m}^{3}$ (Lewis et al., 1988; Hyndman and Lewis, 1995). This model does not include the local thermal effects of deformation and thickening or fluid expulsion in the accretionary prism. The measured heat flow generally is in good agreement with the model values. Heat flow is high $\left(\sim 120 \mathrm{~mW} / \mathrm{m}^{2}\right)$ in the Cascadia Basin associated with the very young oceanic crust, $\sim 6-7 \mathrm{Ma}$ in age (Fig. F2). The heat flow decreases inland of the trench as a result of the heat sink of the cold upper part of the oceanic plate that is underthrusting the margin (e.g., Hyndman and Wang, 1993; Wang et al., 1995). Heat flow data are available from land boreholes and petroleum exploration wells on the continental shelf (Lewis et al., 1988, 1991), marine probe measurements on the continental slope and Cascadia Basin (Davis et al., 1990; Hyndman et al., 1993; Spence et al., 2000b; Riedel, 2001; Riedel et al., 2006), and from the depth of the BSR on the continental slope (Hyndman et al., 1993, 1992; Ganguly et al., 2000; Riedel, 2001; He et al., 2003).

The regional heat-probe measurements in 1990 and 1992 near Site 889 show values between 80 and 110 $\mathrm{mW} / \mathrm{m}^{2}$, whereas the repeat measurements carried out in 2000 along almost the same profile show values between 50 and $75 \mathrm{~mW} / \mathrm{m}^{2}$ (Fig. F5). The reason for this discrepancy is still unresolved, but variations over months to a few years in bottom water temperature are the most likely explanation.

A more reliable estimate for the deeper heat flow may be achieved from BSR depth conversions (e.g., Yamano et al., 1982; Davis et al., 1990; Hyndman et al., 1993; Ganguly et al., 2000; He et al., 2003). The BSR closely approximates the base of the GHSZ, and because of the strong temperature influence on gas hydrate stability, the BSR approximately marks an isotherm and therefore can be used to determine heat flow. Heat flow calculations require three main parameters:

1. The depth to the BSR (from reflection time and average seismic velocity),

2. The temperature at the BSR (from stability field), and

3. The average thermal conductivity to the depth of the BSR (from core measurements and empirical velocity-conductivity relations).

Traveltimes to the seafloor and BSR have to be determined from the seismic sections and are converted into BSR depth using a simplified velocity-depth function. The estimated heat flow is not very sensitive to variations in the velocity profile used because a change in BSR depth also results in a compensating change in BSR temperature without significantly changing the temperature gradient. Thermal conductivity was determined using the empirical regression given by Davis et al. (1990) based on ODP core data. A simple conductive model adapted from Ganguly et al. (2000) was used to convert BSR depth to surface heat flow in the area of Site 889 from regional seismic lines (He et al., 2003). Most of the heat flow variation is due to topographic changes across the two ridges of accreted sediments (Fig. F6). A comparison of heat probe measurements from the 2000 survey along seismic Line PGC9902_ODP2 with BSR-derived heat flow values is shown in Figure F5. The two campaigns of probe measurements are significantly different, as mentioned above, and the BSR-derived estimates are between the two and probably forms the most reliable estimate.

Using the temperature gradient estimate at Site 889 from downhole data of $54^{\circ} \mathrm{C} / \mathrm{km}$ and an estimated average thermal conductivity of $1.15 \mathrm{~W} /(\mathrm{m} \cdot \mathrm{K})$, the heat flow at this site is $62 \pm 8 \mathrm{~mW} / \mathrm{m}^{2}$ (Westbrook et al., 1994). This value is significantly less than the probe measurements carried in 1990 and $1992 \sim 3500$ and $800 \mathrm{~m}$ south of the drill site, respectively. However, measurements carried out in 2000 over the vent field, $\sim 1 \mathrm{~km}$ south of Site 889 , average $\sim 60 \mathrm{~mW} / \mathrm{m}^{2}$ and are in excellent agreement with the borehole estimate. The BSR-derived heat flow around Site 889 is slightly higher, with values just below $70 \mathrm{~mW} / \mathrm{m}^{2}$. 


\section{Gas hydrate concentration estimates and no-hydrate, no-gas baselines}

Regional concentrations of gas hydrate beneath the northern Cascadia continental slope off Vancouver Island have been estimated earlier using MCS (Yuan et al., 1996, 1999), seafloor CSEM (Yuan and Edwards, 2001; Schwalenberg et al., 2005), and Leg 146 downhole data, including pore water salinity, electrical resistivity, and sonic velocity data (Hyndman et al., 1999, 2001; Spence et al., 2000a). The estimated concentrations of between $15 \%$ and $30 \%$ of pore saturation in a $100 \mathrm{~m}$ thick layer above the BSR are much higher than estimated elsewhere, especially the Blake Ridge (Paull et al., 1996) and central Cascadia off Oregon during Leg 204 (Tréhu, Bohrmann, Rack, Torres, et al., 2003). Although both of these other studies involved different sediment environments, a careful reevaluation of the northern Cascadia estimates and their uncertainties was carried out by Riedel et al. (2005). They concluded that the data and model uncertainties allowed a wide range of concentrations.

\section{Electrical resistivity}

Gas hydrate concentrations may be estimated from downhole electrical resistivity (e.g., Collett and Ladd, 2000; Hyndman et al., 1999) because, compared to the saline pore water, gas hydrate is a nearly perfect insulator. The resistivity from downhole logs in the Cascadia Basin Site 888 is $\sim 1.0 \Omega \mathrm{m}$ to a depth of several hundred meters, typical of deep-sea oceanbottom sediments. In contrast, the resistivity at gas hydrate Site 889 is much higher $(\sim 2.0 \Omega \mathrm{m})$ (Westbrook et al., 1994). The critical unknown in using this resistivity to estimate gas hydrate concentrations is the no-gas hydrate reference resistivity, which is largely controlled by pore fluid salinity. Pore fluid has substantially lower salinity than normal (near seawater) in the recovered cores at Site 889 , but this may be due to dissociation of in situ gas hydrate after recovery. Hyndman et al. (1999) showed that it is possible to estimate both the in situ pore fluid salinity and the in situ gas hydrate concentration using downhole log resistivity data and porosity and resistivity data from recovered cores. An important uncertainty is the relation between resistivity and porosity described by Archie's relation (Archie, 1942), which was estimated from core measurements.

Archie's relation states:

$$
\sigma_{\mathrm{f}}=\phi^{\mathrm{m}} S_{\mathrm{w}}{ }^{\mathrm{n}} \sigma_{\mathrm{w}} / \mathrm{a},
$$

where

$$
\begin{aligned}
& \sigma_{\mathrm{f}}=\text { formation conductivity, } \\
& \phi=\text { porosity, } \\
& S_{w}=\text { fraction of pore volume filled with water, } \\
& \sigma_{\mathrm{w}}=\text { conductivity of the pore water, } \\
& a=\text { a constant, typically in the range } 1 \leq a \leq 2.5 \text {, } \\
& m=\text { sediment cementation factor in the range of } \\
& 1.5 \leq m \leq 3 \text {, and } \\
& n=\text { saturation exponent in the range } 1.5 \leq \mathrm{n} \leq \\
& 2.2 \text {. }
\end{aligned}
$$

The parameters $a$ and $m$ are determined from purely water-saturated sediments. The parameters may be estimated from core measurements or from downhole resistivity and porosity logs (i.e, gamma ray density or neutron porosity). For logging data, they are typically estimated from a log-log crossplot of formation factor as a function of porosity, generally known as a "Pickett plot" (e.g., Serra, 1984). The parameter $n$ can be estimated by averaging values for different lithologies (Pearson et al., 1983; Collett, 2000). Spangenberg (2001), however, showed that the parameter $n$ is dependent on the grain-size distribution and gas hydrate concentration itself; therefore, there is no "global" value for $n$ that can be used with confidence for the entire sediment column under investigation. Using Leg 146 core data at ODP Sites 888 and 889/890, Hyndman et al., (1999) determined the parameters to be $a=1.4, m=1.76$, and $n=$ $m$. Using the Site 889 resistivity and neutron porosity logs, Collett (2000) estimated significantly different parameters of $a=1.0, m=2.8$, and $n=1.94$. There are significant uncertainties in both $\log$ and core approaches. Core samples may have been significantly disturbed upon recovery, including the effect of gas hydrate dissociation, and there are sampling biases. In turn, the available downhole logs are of low quality because of hole enlargements, and the logs only measure porosity indirectly. The differences in these empirical parameters result in substantially different gas hydrate concentrations. Using the Archie parameters of Hyndman et al. (1999) yield the highest concentrations, which are on average $30 \%$ of the pore space in an interval of $100 \mathrm{~m}$ above the BSR. Alternatively, using the Collett (2000) parameters yields much smaller concentrations that are on average only $5 \%$ of the pore space.

\section{Pore water chlorinity/salinity}

Dissociation of gas hydrate releases methane and freshwater; therefore, pore water in recovered cores that is fresher than the assumed background level is commonly taken as an indication of in situ presence of gas hydrate that has dissociated upon core recovery. This process has been used widely to estimate gas hydrate concentrations (e.g., Hesse and Harrison, 1981; Hesse, 2003; Kastner et al., 1995; Ussler and 
Paull, 2001). The limitation of the method, however, is the problem of estimating the background (or reference) in situ pore fluid chlorinity/salinity before gas hydrate dissociation upon recovery. The in situ chlorinity/salinities may be strongly affected by the formation of gas hydrate (i.e., values higher than seawater) and by a number of geochemical processes, such as clay dehydration, that give values lower than seawater (Torres et al., 2004). Torres et al. (2004) argued that much of the low salinity in cores from Site 889 was due to geochemical processes not caused by dissociation of in situ hydrate. Figure F7 shows pore water salinities from Site $889 / 890$ in comparison to data from Site 888 and Leg 204 (Holes 1244C, 1251B, and $1252 \mathrm{~A})$. The two extreme models for the reference are

1. A strongly decreasing smoothed profile through the Site 889 data such that only the local deviations represent freshening by gas hydrate that dissociated upon recovery, similar to the assumption by Ussler and Paull (2001) for the Blake Ridge; or

2. The chlorinity/salinity from the Cascadia Basin well Site 888, which is close to that of seawater.

Use of core pore fluid salinity data along with electrical resistivity data allows independent calculation of both the in situ reference salinity and the gas hydrate concentrations (Hyndman et al., 1999). However, as discussed above, the results are strongly dependent on the estimated Archie parameters. Within the estimated range of Archie's parameters the derived in situ pore water salinities (i.e., before gas hydrate dissociation in recovered cores) either fall on a decreasing salinity reference profile, similar to that observed in the recovered core, or on a near-seawater reference, as at Cascadia Basin reference Site 888. Consequently, Site 889/890 gas hydrate concentrations can either range between $5 \%$ and $10 \%$ or $30 \%$ and $40 \%$, depending on the no-gas hydrate reference salinity used (Riedel et al., 2005).

\section{Seismic $\boldsymbol{P}$-wave velocity}

Seismic velocities from ODP sonic logs, downhole vertical seismic profiles (VSPs), and MCS data can be used to calculate gas hydrate concentrations, if an appropriate no-gas hydrate velocity-depth profile can be estimated. All the empirical methods to obtain gas hydrate concentrations from velocity data depend on a no-gas, no-gas hydrate reference velocity-depth profile. There are several different approaches to define this reference relation. The first approach is to determine the velocity-depth from MCS or downhole log data in a sediment section with a similar composition and state that contains no gas hydrate (e.g., Site 888). However, the porosity-depth and velocity-depth profiles for no gas hy- drate may be quite different in the accretionary prism because of tectonic shortening and overpressure. The second approach is to use the deeper velocity-depth section from MCS data in the area well below the BSR where no gas hydrate or gas is expected and interpolate smoothly to near-surface velocities, where again no regional gas hydrate is expected. Yuan et al. (1996) applied this method to Site 889/ 890; we recently carried out more extensive semblance velocity analyses in the area (Fig. F8B), and the results confirm the general velocity-depth trends observed by Yuan et al. (1996) but added new detailed information, especially just below the BSR. A third approach is to use downhole log gamma density or neutron porosity data from the hydrate section. These parameters, which are expected to be little affected by the presence of gas hydrate, may be converted to no-gas hydrate velocity using normal no-gas hydrate velocity-density or velocity-porosity relations. The same approach can use ODP core porosity or density data, after dissociation of any gas hydrate). A fourth approach is to employ rock physics modeling by using core porosity and grain composition to calculate a theoretical velocity (e.g., Helgerud et al., 1999; Dvorkin and Nur, 1993).

Depending on which no-gas hydrate/no-gas velocity baseline is used, estimated gas hydrate concentrations at Site $889 / 890$ range from as low as 5\% to $>25 \%$ saturation (Fig. F8). The various velocity baselines shown in Figure F8 were calculated from smoothed downhole core porosity data fitted using Athy's law (Athy, 1930). Background profiles based on the smoothed porosity data were calculated using the Lee et al. (1993) weighted mean equation, the Hyndman et al. (1993) porosity-velocity relation, and an empirical porosity-velocity relation by Jarrad et al. (1995). All these core-based baselines are substantially above the reference profile by Yuan et al., (1996), based on seismic interval velocities, and therefore result in lower gas hydrate concentration estimates of $<10 \%$ of the pore space.

In spite of having four nearly independent methods of estimating gas hydrate concentrations, Riedel et al. (2005) concluded that the data still allow regional concentrations above the BSR that range from $<5 \%$ to $>25 \%$ saturation ( $3 \%-13 \%$ of sediment volume). The uncertainties come mainly from the difficulty of obtaining no-gas hydrate/no-gas reference profiles with depth, (i.e., velocity, resistivity, and pore fluid salinity).

\section{Free gas concentrations}

To estimate the amount of free gas below the BSR, the main constraint is the reduction in $P$-wave velocity. Again, a no-gas velocity reference is needed. In 
the case of gas, however, this is less a source of error than for gas hydrate because even a small amount of gas decreases the velocity substantially, and velocities much below that of water are not expected except in the presence of gas. The amount of free gas can be estimated from velocity data using the BiotGassmann theory (Desmons, 1996), which includes the effect of pressure $(P)$ and temperature $(T)$ on gas compressibility. Both parameters can be estimated from the general gas hydrate phase diagram. $P$-wave velocity was calculated as function of free gas concentration for the Site 889 region (Desmons, 1996). $P$-wave velocity drops to values as low as $800 \mathrm{~m} / \mathrm{s}$, but all major changes occur within the first 5\%-10\% gas saturation. There are two constraints from VSP and regional MCS data showing decreasing $P$-wave velocity values that can be used to estimate the amount of free gas below the BSR near Site 889 (Fig. F8). The VSP data show a decrease to values of $\sim 1480 \mathrm{~m} / \mathrm{s}$, and newly determined interval velocities from MCS Line 89-08 show an even further decrease to values $\sim 1400 \mathrm{~m} / \mathrm{s}$ below the BSR. These velocities are equivalent to a gas concentration of $<1 \%$ of the pore space.

Using the effective medium theory by Helgerud et al. (1999), the $P$-wave velocity for unconsolidated marine sediments was calculated for the presence of free gas at Site 889 (Riedel, 2001). The amount of $\sim 1 \%$ of free gas results in a seismic $P$-wave velocity of $\sim 1480$ $\mathrm{m} / \mathrm{s}$, similar to the lowest values determined from the VSP experiment at Site 889 (MacKay et al., 1994).

\section{Cold vents}

Much of the recent work on gas hydrate off Vancouver Island has been on seismic blank zones that are interpreted to be cold fluid and gas vents and that contain shallow massive gas hydrate. One cold vent area has been well studied, but there is not widespread high-frequency seismic data to estimate how common such vents are on the margin, as they are not easily seen on conventional low-frequency MCS data. A number of cold vents characterized by seismic blank zones have been identified within a closely spaced area on an uplifted sediment block near Site 889 (Riedel et al., 2002), as well as $\sim 2 \mathrm{~km}$ north and $\sim 5 \mathrm{~km}$ southwest of the site (Riedel, 2001). This cold vent field, $\sim 4 \mathrm{~km} \times 2 \mathrm{~km}$, consists of at least four vents associated with small-scale near-surface faults (Fig. F9). The most prominent vent (referred to as Bullseye), which is $\sim 400 \mathrm{~m}$ across, has been the subject of intensive geophysical and geochemical studies since 1999 (Novosel et al., 2005; Lu et al., 2005; Riedel et al., 2002; Solem et al., 2002; Schwalenberg et al., 2005; Willoughby et al., 2005;
Wood et al., 2002; Zühlsdorff and Spiess, 2004). A hydrate cap is evident in high-resolution seismic data, and gas hydrate within the upper 2-8 meters below seafloor (mbsf) was recovered by piston coring. Several different mechanisms have been proposed for the origin of the seismic blanking and the associated implications concerning the nature of the fluid venting. Riedel et al. (2002) suggested that much of the blanking is due to near-surface carbonate or the massive gas hydrate layer at the surface; additional blanking may be due to scattered accumulations of gas hydrate in the subsurface. Zühlsdorff and Spiess (2004) proposed that the oblong shape of the blank zone and its associated surface mound are created by natural hydraulic fracturing induced by a local elevation in the seafloor and BSR. The blanking is produced by free-gas bubbles within the fractures, particularly in the period following a fluid expulsion event. Wood et al. (2002) argued that the entire blank zone is a gas chimney produced by rising warm fluids that significantly perturb the base of gas hydrate stability upward. In a recent summary, Riedel et al. (2006) proposed a model that incorporates elements of the previous models, where the blank zone is produced by either gas hydrate or gas that has a channeled or filamentous distribution produced by fractures of varying scales in the sediments. Small fractures may be lined with high concentrations of gas hydrate, which can act as an impermeable barrier that traps free gas within the channels. However, the lack of a strong seismic velocity anomaly indicated that the total volume occupied by these fractures must be a small portion of the total volume of the vent, and so the overall amount of gas hydrate or gas must be volumetrically small. The model is also consistent with highly localized vent outlets that may be episodically active, perhaps at the time of great earthquakes. Understanding the composition, structure, gas hydrate and gas content, and origin of these blank zone structures is a very important topic for future study.

\section{Summary of vent structure seismic observations}

This $4 \mathrm{~km} \times 2 \mathrm{~km}$ vent field is characterized by a dense population of seismic blank zones. These subvertical zones of reduced seismic reflection amplitude have been observed using a variety of seismic recording systems and source frequencies, but they are especially prominent in the higher frequency data. Blank zones were first identified on DTAGS data in 1997 using frequencies from 250 to $650 \mathrm{~Hz}$ (Wood et al., 2000) and were subsequently imaged using two-dimensional (2-D) and 3-D single- and multichannel seismic systems. The blank zones 
range from 80 to several $100 \mathrm{~m}$ in width, and blanking is restricted to the upper slope-sediment section above the BSR. The majority of the deeper accreted sediments, however, lack coherent reflectivity and blanking cannot be distinguished from the generally chaotic low reflectivity of the sediments at these depths that we associate with pervasive deformation. Blanking increases with increasing seismic frequency (Riedel et al., 2002). A typical characteristic of seismic images across the vent field are diffraction hyperbolas at the edges of the blank zones (Fig. F10), which artificially enhance stratigraphic reflector strength in the area and result in bright rims around the edges in 3-D seismic time slices (Fig. F11).

In lower frequency seismic data, several reflectors can be traced through the blank zones, but they show very little up-warping or down-warping indicative of changes in seismic velocity across the vents. Seismic velocity analyses carried out at several vents also did not detect any significant lateral changes. The lack of a seismic velocity anomaly may be explained by either the blanking produced by small amounts of gas hydrate or free gas or by a balancing combination of high amounts of gas hydrate with a few percent of free gas. Also, no significant velocity anomaly was detected using traveltime tomography from five OBSs deployed over the main cold vent (Zykov and Chapman, 2004), although massive gas hydrate was recovered from near the seafloor at this vent and the top of the gas hydrate was mapped seismically as a dome-shaped cap reflector (Fig. F11).

\section{Summary of piston coring}

The seismic surveys were complemented by two piston coring campaigns. In 2000, a total of 24 cores were taken in the area of the cold vent field, mainly over Bullseye vent and blank Zone 4 with additional cores located outside the blank zone area to verify background sediment properties. Further piston coring was carried out along an east-west transect across Bullseye vent in 2002 for more detailed geochemical analyses (Pohlman et al., 2003). The cored sediment mostly consisted of finely laminated glaciomarine clays and silts with occasional layers of sands and silts (Novosel, 2002). Detailed core physical property measurements were carried out to document sediment alterations as a result of upward methane advection and gas hydrate formation (Novosel, 2002; Novosel et al., 2005). Although thermal conductivity, density, and porosity showed only slight differences in sediments from within the seismically blank zones compared to the surrounding area, by far the strongest signal was detected in magnetic susceptibility (Novosel et al., 2005). The magnetic susceptibility of cores located within Bullseye vent is dramat- ically lower than the values for cores located outside this area (Fig. F12). The cores within the area of blanking have very low magnetic susceptibilities between 50 and $800 \times 10^{-6} \mathrm{SI}$, whereas cores from outside the blanking area have susceptibilities several orders of magnitude higher, from $2000 \times 10^{-6}$ to 4000 $\times 10^{-6} \mathrm{SI}$. The reduction in magnetic susceptibility is associated with the formation of authigenic pyrite (Novosel et al., 2005).

Piston coring recovered massive hydrate at Bullseye vent at depths of 1-8 mbsf. The near-seafloor seismic data image the top of the hydrate as a shallow reflector around the center of the blank zone at similar depths to the cored gas hydrate (Fig. F11).

Geochemical profiles in the piston cores were also used to determined fluid flux rates (Solem et al., 2002). Sulfate reduction profiles as a function of depth represent a balance between upward methane advection and downward oxidation diffusion from the seafloor. In the background cores from outside the seismic blanking area to the southwest and northeast of Bullseye vent, the calculated methane flux varies from 10 to $19 \mathrm{~mol} /\left(\mathrm{m}^{2} \cdot \mathrm{k} . \mathrm{y}.\right)$, and the sulfate/methane interface (SMI) is generally deeper than $6 \mathrm{~m}$. Within Bullseye vent, the methane flux is higher, varying from 32 to $60 \mathrm{~mol} /\left(\mathrm{m}^{2} \cdot \mathrm{k} . \mathrm{y}\right.$.), with the SMI being typically between 3 and 6 mbsf. In one core from the 2002 campaign, however, the SMI was very close to the seafloor. This site had the shallowest occurrence of near-seafloor massive gas hydrate (Pohlman et al., 2003).

\section{Seafloor video observations}

The 2000 coring cruise was followed by surveys with the Remotely Operated Platform for Ocean Sciences (ROPOS) in August 2000 and May 2001 to examine the seafloor environment around Bullseye vent. At several locations, large outcrops of carbonates were found (Riedel et al., 2002). Typically, the 10-15 cm thick carbonate sheets covered a seafloor area of several square meters and were located around relatively steep ridges $\sim 3 \mathrm{~m}$ high. The carbonates often outcropped along multiple lineaments. Along one of these lineaments, samples of the carbonate outcrop were collected and analyzed for carbon isotopic composition. The low isotopic weights of about $-45 \%$ indicate that the carbonate is formed mainly by oxidation of biogenic methane. Additional carbonate outcrops were found at blank Zone 3 as thin plates almost parallel to the seabed. There was no obvious surface elevation associated with the carbonate outcrops. A single live clam community of vesicomyids associated with worms and bacteria mats was observed at Bullseye vent during the ROPOS cruise in 2001 (Riedel et al., 2002). These chemosynthetic 
communities indicate active methane venting and related sulfide emissions. The clams formed smallscale colonies 1-2 $\mathrm{m}$ in diameter aligned around a small carbonate ridge. Several water samples were taken with ROPOS in a vertical profile above this clam colony showed a methane plume in the water column up to $\sim 250 \mathrm{~m}$ above the seafloor.

\section{New alternative surveying techniques}

In the most recent studies, two new geophysical surveying techniques have been developed at the University of Toronto, CSEM sounding and seafloor compliance measurements, were applied at the vent field (especially Bullseye vent) to overcome some of the seismic imaging difficulties and related model uncertainties from the earlier studies (Schwalenberg et al., 2005; Willoughby et al., 2005) These methods are sensitive to physical properties of the sedimentary section, which are modified by gas hydrate, namely, electrical resistivity and bulk shear modulus.

Seafloor compliance is primarily sensitive to shear modulus, and therefore shear velocity, as a function of depth. Gas hydrate, which displaces pore fluids and cements the sediment grains, increases the shear modulus of the sediment column. Willoughby and Edwards (2000) found higher than normal shear velocities within the GHSZ from compliance studies near Site 889 . This method was subsequently applied over the cold vent field. The new deployments over and adjacent to two of the vents show significant increases in shear modulus with depth (Fig. F13). The anomalous compliance results over the two vent sites indicate a large increase in shear modulus within the GHSZ, particularly near the base, suggesting a significant gas hydrate concentration.

The seafloor-towed CSEM system was successfully deployed in several areas on the northern Cascadia margin over the past several years (Edwards, 1997; Yuan and Edwards, 2001). Data from initial deployments around Site 889 showed an average resistivity of $\sim 2 \Omega \mathrm{m}$ for the $100 \mathrm{~m}$ thick layer overlying the BSR (Yuan and Edwards, 2001). This is in very good agreement with the downhole electric resistivity logs (e.g., Hyndman et al., 1999) and a factor of two higher than the log resistivities in deep-sea basin Site 888 , where no gas hydrate is expected. As discussed above, it is not yet clear whether the high resistivity is mainly a result of hydrate or unusually low salinity pore fluid. More recent deployment of the CSEM array over the seismically mapped cold vents showed dramatic high-resistivity anomalies (Schwalenberg et al., 2005) as illustrated in Figure F14. The resistivity values within the anomalous zones rise locally to $>5 \Omega \mathrm{m}$, about four times the regional background of 1.1-1.5 $\Omega \mathrm{m}$. The resistivity values were converted to gas hydrate concentrations using both the Archie parameters of Hyndman et al. (1999) and those of Collett (2000). For both sets of coefficients, comparable amounts of gas hydrate are required to explain the observed resistivity anomalies. For Bullseye vent, the additional gas hydrate concentration reaches as much as $50 \%$ of the pore space (Schwalenberg et. al., 2005). It should be noted that the method has poor depth resolution and the concentration estimates are averages for a depth interval of several hundred meters.

\section{Drilling objectives}

The primary objective of Expedition 311 on the northern Cascadia margin is to constrain geologic models for the formation of gas hydrate in subduction zone accretionary prisms. Natural gas hydrate occurs in marine continental slope and onshore Arctic permafrost environments. The Arctic occurrences can exhibit locally very high gas hydrate concentrations but appear to contain less total gas than marine gas hydrate occurrences. Recent studies have suggested that the largest total amounts of gas hydrate may lie in nearly horizontal layers several hundred meters beneath the seafloor of continental slopes, especially in the large subduction zone accretionary sedimentary prisms. Gas hydrate and underlying free gas produce the ubiquitous bottom-simulating reflectors along numerous continental margins of the world. Gas hydrate does occur on passive margins, but it is less common and appears at usually lower concentrations.

Expedition 311 followed the goals for gas hydrate drilling as proposed by the ODP Gas Hydrates Program Planning Group:

- Study the formation of natural gas hydrate in marine sediments.

- Determine the mechanism of development, nature, magnitude, and global distribution of gas hydrate reservoirs.

- Investigate the gas transport mechanism and migration pathways through sedimentary structures from site of origin to reservoir.

- Examine the effect of gas hydrate on the physical properties of the enclosing sediments, particularly as it relates to the potential relationship between gas hydrate and slope stability.

- Determine no-gas hydrate/no-gas baselines for pore water chlorinity, physical properties $(P$ - and $S$-wave velocity) and for the empirical Archie parameters to use electrical resistivity.

- Investigate the microbiology and geochemistry associated with hydrate formation and dissociation. 
The objectives of this expedition were to test gas hydrate formation models and constrain model parameters, especially models of hydrate concentration through upward fluid and methane transport. The new site survey data and compilation of previous data summarized above are in support of these objectives. The IODP objectives require

- High-quality data on the vertical concentration distributions of gas hydrate and free gas and variation landward in the accretionary prism and

- Estimates of the vertical fluid and methane fluxes through the sediment section as a function of landward distance from the deformation front.

The study will concentrate on the contrast between dispersed pervasive upward flow and focused flow of fluid and methane in fault zones. The pervasive permeability may be on a grain or centimeter scale (the scaly fabric observed in previous ODP clastic accretionary prism cores) or in closely spaced faults.

\section{Post-Expedition 311 outlook}

The 553-Full2 "Cascadia Gas Hydrate" proposal included monitoring and a number of measurements that were not possible in the scheduled expedition. They are now proposed for a future, second expedition to the area and include long-term monitoring experiments using Circulation Obviation Retrofit Kits (CORK-II and Advanced CORK) and vertical distributed temperature sensing (DTS) systems. These long-time monitoring devices will be permanently installed at various sites along the transect including the cold vent setting to study

- Temporal changes in the temperature regime associated with fluid and gas flow;

- Formation pressure variations associated with fluid flow, especially to determine if there is a connection between earthquake activity and periods of more active fluid flow at the cold vent; and

- Permeability on various length scales with a hydro-geologic cross-hole ACORK experiment.

An additional objective is to more precisely constrain the extent of the gas hydrate stability zone, by using DTS cables rather than the Advanced Piston Coring Temperature (APCT) or Davis Villinger Temperature-Pressure (DVTP) tools, which take only widely spaced downhole temperature measurements. The DTS cables allow measurement of the temperature field at higher vertical resolution, permitting mapping of fluid flow by nonlinear temperature gradients and also monitoring of temporal vertical gradient changes, especially at the base of the GHSZ.
These long-time monitoring devices will eventually be connected to the NEPTUNE cable observatory that will be installed on the Juan de Fuca plate by summer 2008. The planned cable route follows the proposed Expedition 311 transect and includes a node at proposed Site CAS-01B near Site 889 that would allow multiple instrument installations and extension cables. The borehole experiments are also complemented by other NEPTUNE experiments and monitoring, such as seafloor electromagnetic imaging with permanently installed receivers and transmitters, an ocean-bottom seismograph network, near-seafloor high-resolution temperature monitoring, and seafloor video observations, as well as chemical sensors to measure and record time variations in the amount of methane and other tracers in the water column.

\section{References}

Athy, L.F., 1930. Density, porosity, and compaction of sedimentary rocks. AAPG Bull., 14:1-24.

Archie, G.E., 1942. The electrical resistivity log as an aid in determining some reservoir characteristics. J. Pet. Technol., 5:1-8.

Chapman, N.R., Gettrust, J., Walia, R., Hannay, D., Spence, G.D., Wood, W., and Hyndman, R.D., 2002. High-resolution, deep-towed, multichannel seismic survey of deep-sea gas hydrates off western Canada. Geophysics, 67(4):1038-1047. doi:10.1190/1.1500364

Clowes, R.M., Brandon, M.T., Green, A.G., Yorath, C.J., Brown, A.S., Kanasewich, E.R., and Spencer, C., 1987a. LITHOPROBE—southern Vancouver Island: Cenozoic subduction complex imaged by deep seismic reflections. Can. J. Earth Sci., 24:31-51.

Clowes, R.M., Yorath, C.J., and Hyndman, R.D., 1987b. Reflection mapping across the convergent margin of western Canada. Geophys. J. R. Astron. Soc., 89:79-84.

Collett, T.S., 2000. Quantitative well-log analysis of in-situ natural gas hydrates [Ph.D. dissert.]. Colorado School of Mines, Golden.

Collett, T.S., and Ladd, J., 2000. Detection of gas hydrate with downhole logs and assessment of gas hydrate concentrations (saturations) and gas volumes on the Blake Ridge with electrical resistivity log data. In Paull, C.K., Matsumoto, R., Wallace, P.J., and Dillon, W.P. (Eds.), Proc. ODP, Sci. Results, 164, 179-191 [Online]. Available from World Wide Web: http://www-odp.tamu.edu/ publications/164_SR/VOLUME/CHAPTERS/ SR164_19.PDF

Davis, E.E., and Hyndman, R.D., 1989. Accretion and recent deformation of sediments along the northern Cascadia subduction zone. Geol. Soc. Am. Bull., 101(11):1465-1480. doi:10.1130/00167606(1989)101<1465:AARDOS>2.3.CO;2

Davis, E.E., Hyndman, R.D., and Villinger, H., 1990. Rates of fluid expulsion across the northern Cascadia accretionary prism: constraints from new heat flow and mul- 
tichannel seismic reflection data. J. Geophys. Res., 95:8869-8889.

Dehler, S.A., and Clowes, R.M., 1992. Integrated geophysical modeling of terranes and other structural features along the western Canadian margin. Can. J. Earth Sci., 29:1492-1508.

Desmons, B., 1996. Integrated study of gas hydrates in marine sediments using geophysical and geochemical data [M.Sc. dissert.]. Univ. Victoria, Canada.

Dvorkin, J., and Nur, A., 1993. Rock physics for characterization of gas hydrates. In The Future of Energy Gases. Geol. Surv. Prof. Pap. U.S., 1570.

Edwards, R.N., 1997. On the resource evaluation of marine gas hydrate deposits using sea-floor transient electric dipole-dipole method. Geophysics, 62:63-74. doi:10.1190/1.1444146

Fink, C.R., and Spence, G.D., 1999. Hydrate distribution off Vancouver Island from multifrequency single-channel seismic reflection data. J. Geophys. Res., 104:29092922. doi:10.1029/98JB02641

Fisher, M.A., Brocher, T.M., Hyndman, R.D., Tréhu, M., Weaver, C.S., Creager, K.C., Crosson, R.S., and Parsons, T., 1999. Seismic survey probes urban earthquake hazards in Pacific northwest. Eos, Trans. Am. Geophys. Union, 80(2):13-17.

Ganguly, N., Spence, G.D., Chapman, N.R., and Hyndman, R.D., 2000. Heat flow variations from bottom-simulating reflectors on the Cascadia margin. Mar. Geol., 164(12):53-68. doi:10.1016/S0025-3227(99)00126-7

Hayes, D.E., and Ewing, M., 1970. Pacific plate boundary structure. In Maxwell, A. (Ed.), The Sea: New York (Wiley), 29-72.

He, T., Spence, G.D., Hyndman, R.D., and Chapman, N.R., 2003. Seismic observations of a possible carbonate mound on the continental slope off Vancouver Island. Eos, Trans. Am. Geophys. Union, 84(46) (Fall Meet. Suppl.):OS51C-0867. (Abstract)

Helgerud, M.B., Dvorkin, J., Nur, A., Sakai, A., and Collett, T., 1999. Elastic-wave velocity in marine sediments with gas hydrates: effective medium modeling. Geophys. Res. Lett., 26(13):2021-2024. doi:10.1029/1999GL900421

Hesse, R., 2003. Pore water anomalies of submarine gashydrate zones as tool to assess hydrate abundance and distribution in the subsurface-what have we learned in the past decade? Earth-Sci. Rev., 61:149-179. doi:10.1016/S0012-8252(02)00117-4

Hesse, R., and Harrison, W.E., 1981. Gas hydrates (clathrates) causing pore-water freshening and oxygen isotope fractionation in deep-water sedimentary sections of terrigenous continental margins. Earth Planet. Sci. Lett., 55(3):453-462. doi:10.1016/0012821X(81)90172-2

Hyndman, R.D., 1983. Geothermal heat flux, Juan de Fuca plate map. Juan de Fuca Plate Map Ser., Pacific Geosci. Centre, Geol. Surv. Can.

Hyndman, R.D., 1995. The lithoprobe corridor across the Vancouver Island continental margin: the structural and tectonic consequences of subduction. Can. J. Earth Sci., 32:1777-1802.
Hyndman, R.D., and Davis, E.E., 1992. A mechanism for the formation of methane hydrate and seafloor bottomsimulating reflectors by vertical fluid expulsion. J. Geophys. Res., 97:7025-7041.

Hyndman, R.D., Foucher, J.P., Yamano, M., Fisher, A., Berner, U., Brückmann, W., Byrne, T., Chabernaud, T., Firth, J.V., Gamo, T., Gieskes, J.M., Hill, I.A., Karig, D.E., Kastner, M., Kato, Y., Lallemand, S., Lau, R., Maltman, A.J., Moore, G.F., Moran, K., Olafsson, G., Owens, W.H., Pickering, K., Siena, F., Taira, A., Taylor, E., Underwood, M.B., Wilkinson, C., and Zhang, J., 1992. Deep sea bottom-simulating-reflectors: calibration of the base of the hydrate stability field as used for heat flow estimates.

Earth Planet. Sci. Lett., 109(3-4):289-301. doi:10.1016/ 0012-821X(92)90093-B.

Hyndman, R.D., and Lewis, T.J., 1995. Review: the thermal regime along the southern Canadian Cordollera lithoprobe corridor. Can. J. Earth Sci., 32:1611-1617.

Hyndman, R.D., Moore, G.F., and Moran, K., 1993. Velocity, porosity, and pore-fluid loss from the Nankai subduction zone accretionary prism. In Hill, I.A., Taira, A., Firth, J.V., et al., Proc. ODP, Sci. Results, 131: College Station, TX (Ocean Drilling Program), 211-220.

Hyndman, R.D., and Spence, G.D., 1992. A seismic study of methane hydrate marine bottom simulating reflectors. J. Geophys. Res., 97:6683-6698.

Hyndman, R.D., Spence, G.D., Chapman, N.R., Riedel, M., and Edwards, R.N., 2001. Geophysical studies of marine gas hydrate in northern Cascadia. In Paull, C.K., and Dillon, W.P. (Eds.), Natural Gas Hydrates, Occurrence, Distribution and Detection. Geophys. Monogr., 124:273-295.

Hyndman, R.D., Spence, G.D., Yuan, T., and Davis, E.E., 1994. Regional geophysics and structural framework of the Vancouver Island margin accretionary prism. In Westbrook, G.K., Carson, B., Musgrave, R.J., et al., Proc. ODP, Init. Repts., 146 (Pt. 1): College Station, TX (Ocean Drilling Program), 399-419.

Hyndman, R.D., and Wang, K., 1993. Thermal constraints on the zone of major thrust earthquake failure: the Cascadia subduction zone. J. Geophys. Res., 98:2039-2060.

Hyndman, R.D., Yorath, C.J., Clowes, R.M., and Davis E.E., 1990. The northern Cascadia subduction zone at Vancouver Island: seismic structure and tectonic history. Can. J. Earth Sci., 27(3):313-329.

Hyndman, R.D., Yuan, T., and Moran, K., 1999. The concentration of deep sea gas hydrates from downhole electrical resistivity logs and laboratory data. Earth Planet. Sci. Lett., 172:167-177. doi:10.1016/S0012821X(99)00192-2

Jarrard, R.D., MacKay, M.E., Westbrook, G.K., and Screaton, E.J., 1995. Log-based porosity of ODP sites on the Cascadia accretionary prism. In Carson, B., Westbrook, G.K., Musgrave, R.J., and Suess, E. (Eds.), Proc. ODP, Sci. Results, 146 (Pt 1): College Station, TX (Ocean Drilling Program), 313-335.

Kastner, M., Kvenvolden, K.A., Whiticar, M.J., Camerlenghi, A., and Lorenson, T.D., 1995. Relation between pore fluid chemistry and gas hydrates associated with bottom-simulating reflectors at the Cascadia margin, Sites 889 and 892. In Carson, B., Westbrook, G.K., Musgrave, R.J., and Suess, E. (Eds.), Proc. ODP, Sci. Results, 
146 (Pt 1): College Station, TX (Ocean Drilling Program), 175-187.

Lee, M.W., Hutchinson, D.R., Dillon, W.P., Miller, J.J., Agena, W.F., and Swift, B.A., 1993. Method of estimating the amount of in situ gas hydrates in deep marine sediments. Mar. Pet. Geol., 10(5):493-506. doi:10.1016/ 0264-8172(93)90050-3

Lewis, T.J., Bentkowski, W.H., Davis, E.E., Hyndman, R.D., Souther, J.G., and Wright, J.A., 1988. Subduction of the Juan de Fuca plate: thermal consequences. J. Geophys. Res., 93:15207-15225.

Lewis, T.J., Bentkowski, W.H., and Hyndman, R.D., 1991. Crustal temperatures near the LITHOPROBE southern Canadian Cordilleran transect. Can. J. Earth Sci., 29:1197-1214.

Lu, H., Moudrakovski, I., Riedel, M., Spence, G., Dutrisac, R., Ripmeester, J., Wright, F., and Dallimore, S., 2005. Occurrences and structural characterizations of gas hydrates associated with a cold vent field, offshore Vancouver Island. J. Geophys. Res., 110(B10):B10204. doi:10.1029/2005JB003900

MacKay, M.E., Jarrard, R.D., Westbrook, G.K., and Hyndman, R.D., 1994. Origin of bottom-simulating reflectors: geophysical evidence from the Cascadia accretionary prism. Geology, 22(5):459-462. doi:10.1130/0091-7613(1994)022<0459:OOBSRG $>2.3 . \mathrm{CO} ; 2$

MacLeod, N.S., Tiffin, D.L., Snavely, P.D., and Currie, R.G., 1977. Geologic interpretation of magnetic and gravity anomalies in the Strait of Juan de Fuca, U.S.-Canada. Can. J. Earth Sci., 14:223-238.

Mi, Y., 1998. Seafloor sediment coring and multichannel seismic studies of gas hydrate, offshore Vancouver Island [M.Sc. Thesis]. Univ. Victoria, Canada.

Moore, J.C., and Vrolijk, P., 1992. Fluids in accretionary prisms. Rev. Geophys., 30:113-135.

Novosel, I., 2002. Physical properties of gas hydrate related sediments, offshore Vancouver Island [M.Sc. Thesis]. Univ. Victoria, Canada.

Novosel, I., Spence, G.D., and Hyndman, R.D., 2005. Reduced magnetization produced by increased methane flux at a gas hydrate vent. Mar. Geol., 216:265-274. doi:10.1016/j.margeo.2005.02.027

Paull, C.K., Matsumoto, R., Wallace, P.J., et al., 1996. Proc. ODP, Init. Repts., 164: College Station, TX (Ocean Drilling Program).

Paull, C.K., Ussler, W., III, and Borowski, W.A., 1994. Sources of biogenic methane to form marine gashydrates: in situ production or upward migration? Ann. N. Y. Acad. Sci., 715:392-409.

Pearson, C.F., Halleck, P.M., McGuire, P.L., Hermes, R., and Mathews, M., 1983. Natural gas hydrate deposits: a review of in-situ properties. J. Phys. Chem., 87:41804185.

Pohlman, J.W., Spence, G.D., Chapman, N.R., Hyndman, R.D., Grabowski, K.S., and Coffin, R.B., 2003. Evidence for anaerobic methane oxidation in gas hydrate-rich sediments on the northern Cascadia margin offshore Vancouver Island [EGS-AGU-EUG Joint Assembly, Nice, France, 6-11 April, 2003].
Ramachandran, K., Dosso, S.E., Spence, G.D., Hyndman, R.D., and Brocher, T.M., 2005. Forearc structure beneath southwestern British Columbia: a three-dimensional tomographic velocity model. J. Geophys. Res., 110(B2):B02303. doi:10.1029/2004JB003258

Ramachandran, K., Dosso, S.E., Zelt, C.A., Spence, G.D., Hyndman, R.D., and Brocher, T.M., 2004. Upper crustal structure of southwestern British Columbia from the 1998 Seismic Hazards Investigation in Puget Sound. J. Geophys. Res., 109(B9):B09303. doi:10.1029/ 2003JB002826

Riddihough, R.P., 1984. Recent movements of the Juan de Fuca plate system. J. Geophys. Res., 89:6980-6994.

Riedel, M., 2001. 3D seismic investigations of northern Cascadia marine gas hydrates [Ph.D. dissert.]. Univ. Victoria, Canada.

Riedel, M., Collett, T.S., and Hyndman, R.D. 2005. Gas hydrate concentration estimates from chlorinity, electrical resistivity, and seismic velocity. Geol. Surv. Can. Open-File Rep., 4934.

Riedel, M., Hyndman, R.D., Spence, G.D., and Chapman, N.R., 2002. Seismic investigations of a vent field associated with gas hydrates, offshore Vancouver Island. $J$. Geophys. Res., [Solid Earth], 107(B9):2200. doi:10.1029/ 2001JB000269

Riedel, M., Novosel, I., Spence, G.D., Hyndman, R.D., Chapman, N.R., and Lewis, T., 2006. Geophysical and geochemical signatures associated with gas hydraterelated venting in the northern Cascadia margin. Geol. Soc. Am. Bull., 118(1-2).

Rohr, K.K., 1987. Anatomy of the deformation front, Vancouver Island, Canada. Eos, Trans. Am. Geophys. Union, 68:1467.

Schwalenberg, K., Willoughby, E.C., Mir, R., and Edwards, R.N., 2005. Marine gas hydrate signatures in Cascadia and their correlation with seismic blank zones. First Break, 23:57-63.

Serra, O., 1984. Fundamentals of Well-Log Interpretation (Vol. 1): The Acquisition of Logging Data: Dev. Pet. Sci., 15A: Amsterdam (Elsevier).

Shouldice, D.H., 1971. Geology of the western Canadian continental shelf. Bull. Can. Pet. Geol., 19:405-436.

Shouldice, D.H., 1973. Western Canadian continental shelf. Mem.-Can. Soc. Pet. Geol., 1:7-35.

Singh, S.C., and Minshull, T.A., 1994. Velocity structure of a gas hydrate reflector at Ocean Drilling Program site 889 from a global seismic waveform inversion. J. Geophys. Res., 99:24221-24233.

Singh, S.C., Minshull, T.A., and Spence, G.D., 1993. Velocity structure of a gas hydrate reflector. Science, 260:204207.

Solem, R.C., Spence, G.D., Vukajlovich, D., Hyndman, R.D., Riedel, M., Novosel, I., and Kastner, M., 2002. Methane advection and gas hydrate formation within an active vent field offshore Vancouver Island. Fourth Int. Conf. Gas Hydrates, 19023.

Spangenberg, E., 2001. Modeling of the influence of gas hydrate content on the electrical properties of porous sediments. J. Geophys. Res.,106(B4):6535-6548. doi:10.1029/2000JB900434 
Spence, G.D. Hyndman, R.D., Chapman, N.R., Riedel, M., Edwards, N., and Yuan, J., 2000a. Cascadia margin, northeast Pacific Ocean: hydrate distribution from geophysical investigations. In Max, M.D. (Ed.), Natural Gas Hydrate in Ocean and Permafrost Environments: New York (Kluwer Academic Publisher), 183-198.

Spence, G.D., Hyndman, R.D., Davis, E.E., and Yorath, C.J., 1991a. Multichannel reflection profiles across the Vancouver Island continental shelf and slope. Open-File Rep., Geol. Surv. Can., 2391.

Spence, G.D., Hyndman, R.D., Davis, E.E., and Yorath, C.J., 1991b. Seismic structure of the northern Cascadia accretionary prism: evidence from new multichannel seismic reflection data. In Meissner, R.O., Brown, L.D., Duerbaum, H.-J., Franke, W., Fuchs, K., and Seifert, F. (Eds.), Continental Lithosphere: Deep Seismic Reflections. Am. Geophys. Union, Geodyn. Ser., 22:257-263.

Spence, G.D., Minshull, T.A., and Fink, C., 1995. Seismic studies of methane gas hydrate, offshore Vancouver Island. In Carson, B., Westbrook, G.K., Musgrave, R.J., and Suess, E. (Eds.), Proc. ODP, Sci. Results, 146 (Pt 1): College Station, TX (Ocean Drilling Program), 163-174.

Spence, G.D., Riedel, M., and Novosel, I., 2000b. VENTFLUX: piston coring and heat flow near vent sites associated with marine gas hydrates offshore Vancouver Island. CEOR Report 2000-4, Univ. Victoria, Canada.

Tiffin, D.L., Cameron, B.E.B., and Murray, J.W., 1972. Tectonic and depositional history of the continental margin off Vancouver Island, B.C. Can. J. Earth Sci., 9:280296.

Torres, M.E., Teichert, B.M.A., Tréhu, A.M., Borowski, W., and Tomaru, H., 2004. Relationship of pore water freshening to accretionary processes in the Cascadia margin: fluid sources and gas hydrate abundance. Geophys. Res. Lett., 31:L22305. doi:10.1029/2004GL021219

Tréhu, A.M., Bohrmann, G., Rack, F.R., Torres, M.E., et al., 2003. Proc. ODP, Init. Repts., 204 [CD-ROM]. Available from: Ocean Drilling Program, Texas A\&M University, College Station TX 77845-9547, USA. [HTML]

Ussler, W., III, and Paull, C.K., 2001. Ion exclusion associated with marine gas hydrate deposits. In Paull, C.K., and Dillon, W.P. (Eds.), Natural Gas Hydrates: Occurrence, Distribution, and Detection. Geophys. Monogr., 124:4151.

Wang, K., Mulder, T., Rogers, G.C., and Hyndman, R.D., 1995. Case for very low coupling stress on the Cascadia subduction fault. J. Geophys. Res., 100(B7):12907-12918. doi:10.1029/95JB00516

Westbrook, G.K., 1991. Geophysical evidence for the role of fluids in accretionary wedge tectonics. Philos. Trans. R. Soc. London A, 335:227-242.

Westbrook, G.K., Carson, B., Musgrave, R.J., et al., 1994. Proc. ODP, Init. Repts., 146 (Pt. 1): College Station, TX (Ocean Drilling Program).

Willoughby, E.C., and Edwards, R.N., 1997. On the resource evaluation of marine gas-hydrate deposits using seafloor compliance methods. Geophys. J. Int., 131:751-766.

Willoughby, E.C., and Edwards, R.N., 2000. Shear velocities in Cascadia from seafloor compliance measure- ments. Geophys. Res. Lett., 27:1021-1024. doi:10.1029/ 1999GL010481

Willoughby, E.C., Schwalenberg, K., Edwards, R.N., Spence, G.D., and Hyndman, R.D., 2005. Assessment of marine gas hydrate deposits: a comparative study of seismic, electromagnetic and seafloor compliance methods. Fifth Int. Conf. Gas Hydrates, 3:802-811.

Wood, W.T., Gettrust, J.F., Chapman, N.R., Spence, G.D., and Hyndman, R.D., 2002. Decreased stability of methane hydrates in marine sediments owing to phaseboundary roughness. Nature (London, U. K.), 420:656660. doi:10.1038/nature01263

Wood, W.T., Lindwall, D.A., Gettrust, J.F., Sekharan, K.K., and Golden, B., 2000. Constraints on gas or gas hydrate related wipeouts in seismic data through the use of physical models. Eos, Trans., Am. Geophys. Union, 81(48):F639.

Xu, W., and Ruppel, C., 1999. Predicting the occurrence, distribution, and evolution of methane gas hydrate in porous marine sediments. J. Geophys. Res, 104(B3):50815096. doi:10.1029/1998JB900092

Yamano, M., Uyeda, S., Aoki, Y., and Shipley, T.H., 1982. Estimates of heat flow derived from gas hydrates. Geology, 10:339-343. doi:10.1130/00917613(1982) 10<339:EOHFDF>2.0.CO;2

Yuan, J., and Edwards, R.N., 2001. The assessment of marine gas hydrates through electical remove sounding: hydrate without a BSR? Geophys. Res. Lett., 27(16):23972400. doi:10.1029/2000GL011585

Yuan, T., Hyndman, R.D., Spence, G.D., and Desmons, B., 1996. Seismic velocity increase and deep-sea gas hydrate concentration above a bottom-simulating reflector on the northern Cascadia continental slope. J. Geophys. Res., 101(B6):13655-13671. doi:10.1029/96JB00102

Yuan, T., Spence, G.D., and Hyndman, R.D., 1994. Seismic velocities and inferred porosities in the accretionary wedge sediments at the Cascadia margin. J. Geophys. Res., 99(B3):4413-4427. doi:10.1029/93JB03203

Yuan, T., Spence, G.D., Hyndman, R.D., Minshull, T.A., and Singh, S.C., 1999. Seismic velocity studies of a gas hydrate bottom-simulating reflector on the northern Cascadia continental margin: amplitude modeling and full waveform inversion. J. Geophys. Res., 104(B1):11791192. doi:10.1029/1998JB900020

Zatsepina, O.Y., and Buffett, B.A., 1998. Thermodynamic conditions for the stability of gas hydrate in the seafloor. J. Geophys. Res., 103(B10):24127-24139. doi:10.1029/98JB02137

Zühlsdorff, L., and Spiess, V., 2004. Three-dimensional seismic characterization of a venting site reveals compelling indications of natural hydraulic fracturing. Geology, 32(2):101-104. doi:10.1130/G19993.1

Zykov, M.M., and Chapman, N.R., 2004. 3-D velocity model of hydrocarbon vent site in Cascadia region offshore Vancouver Island [AAPG Hedberg Research Conference: Gas Hydrates: Energy Resource Potential and Associated Geologic Hazards, Vancouver, 12-16 September, 2005].

Publication: 28 October 2006 MS 311-109 
Figure F1. The Cascadia margin and Juan de Fuca plate regime and location of the Expedition 311 coring transect offshore Vancouver Island.

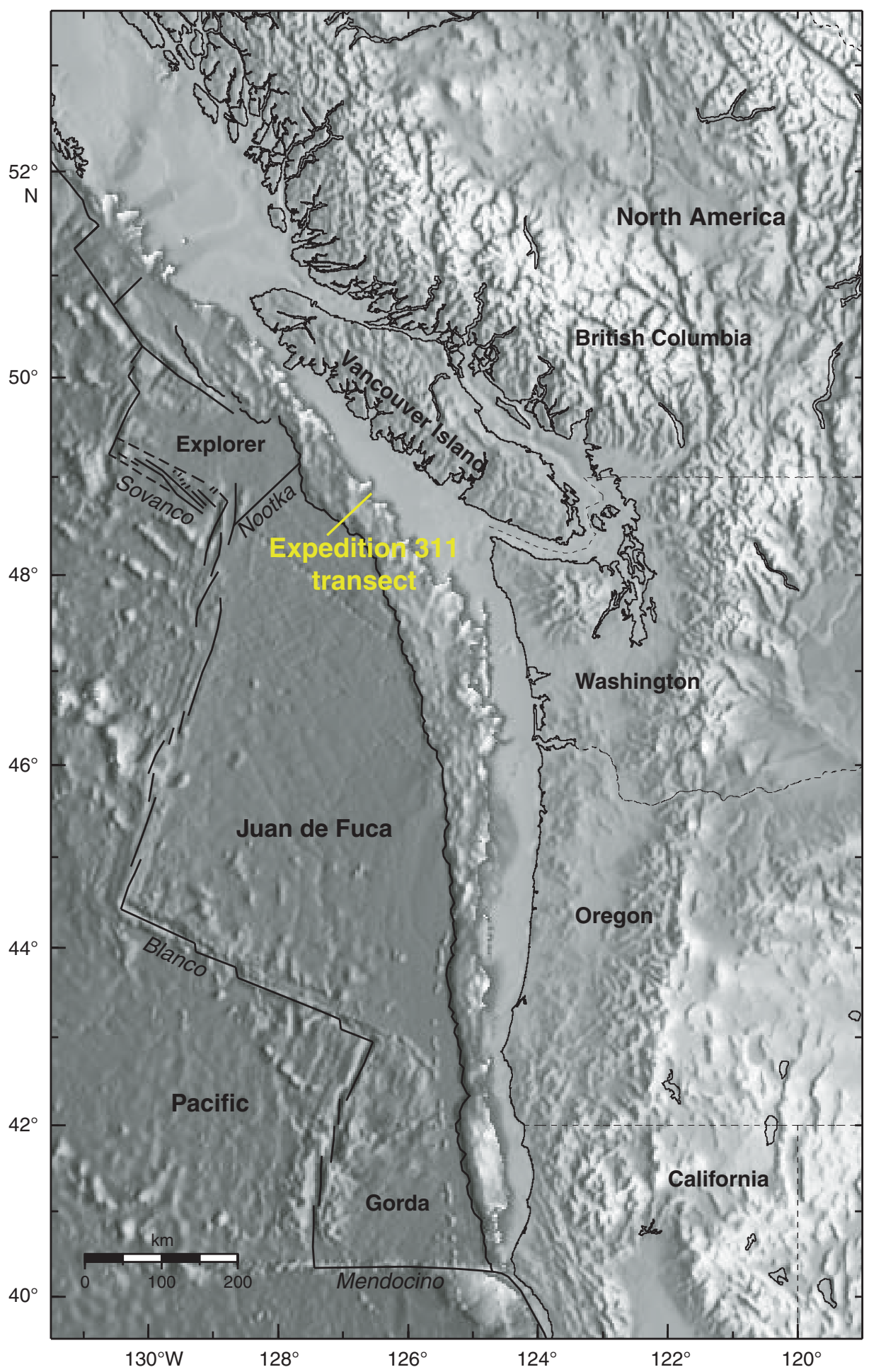


Figure F2. A. Heat flow data in the $100 \mathrm{~km}$ wide LITHOPROBE corridor across the southern Vancouver Island margin. The predicted heat flow from numerical modeling is shown for comparison. BSR = bottom-simulating reflector. B. Offshore-onshore structural cross section across the southern Vancouver Island margin in the LITHOPROBE corridor.

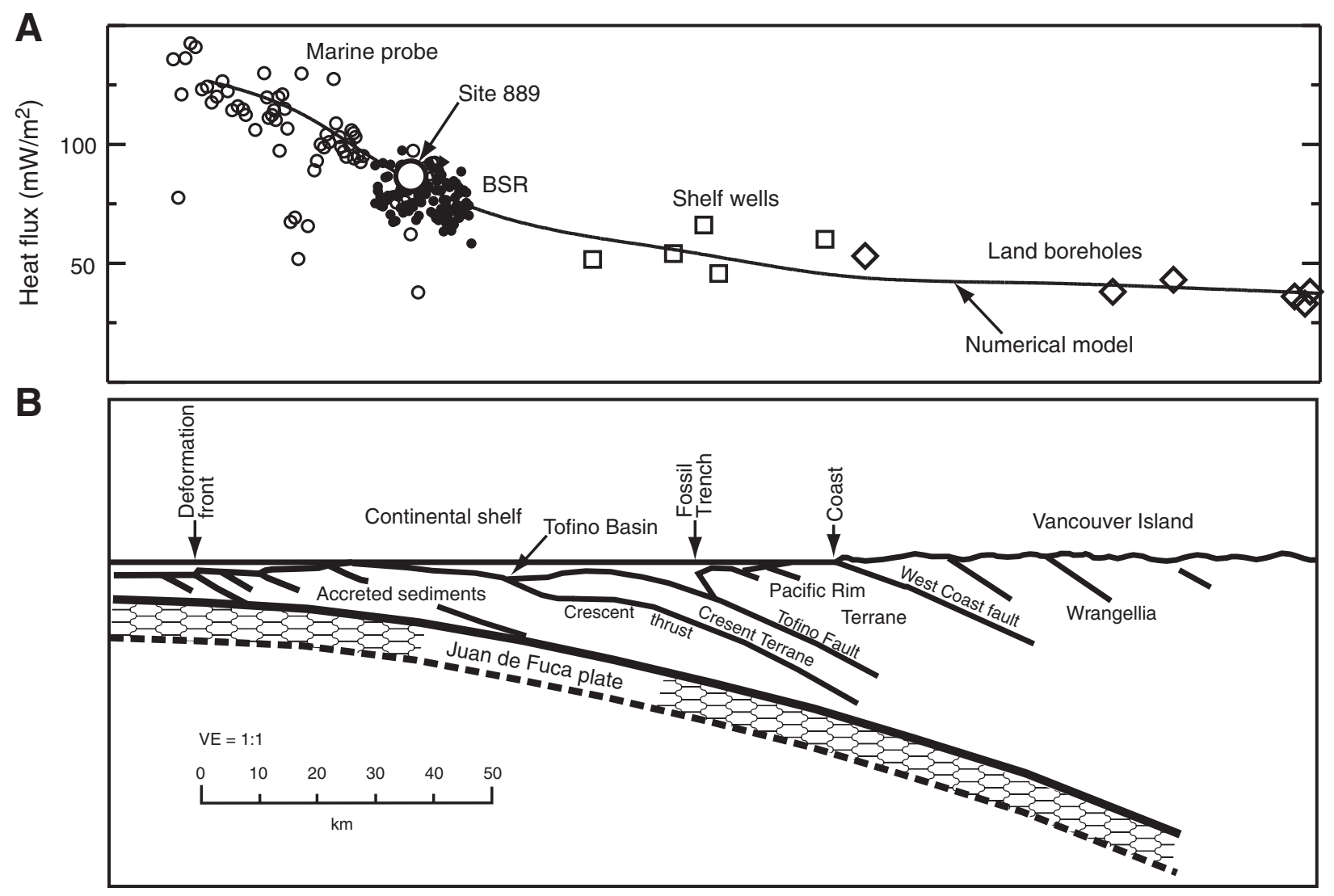


Figure F3. Location of main seismic reflection profiles on the northern Cascadia margin off Vancouver Island $(1985,1989$, and 1999 ODP site surveys).

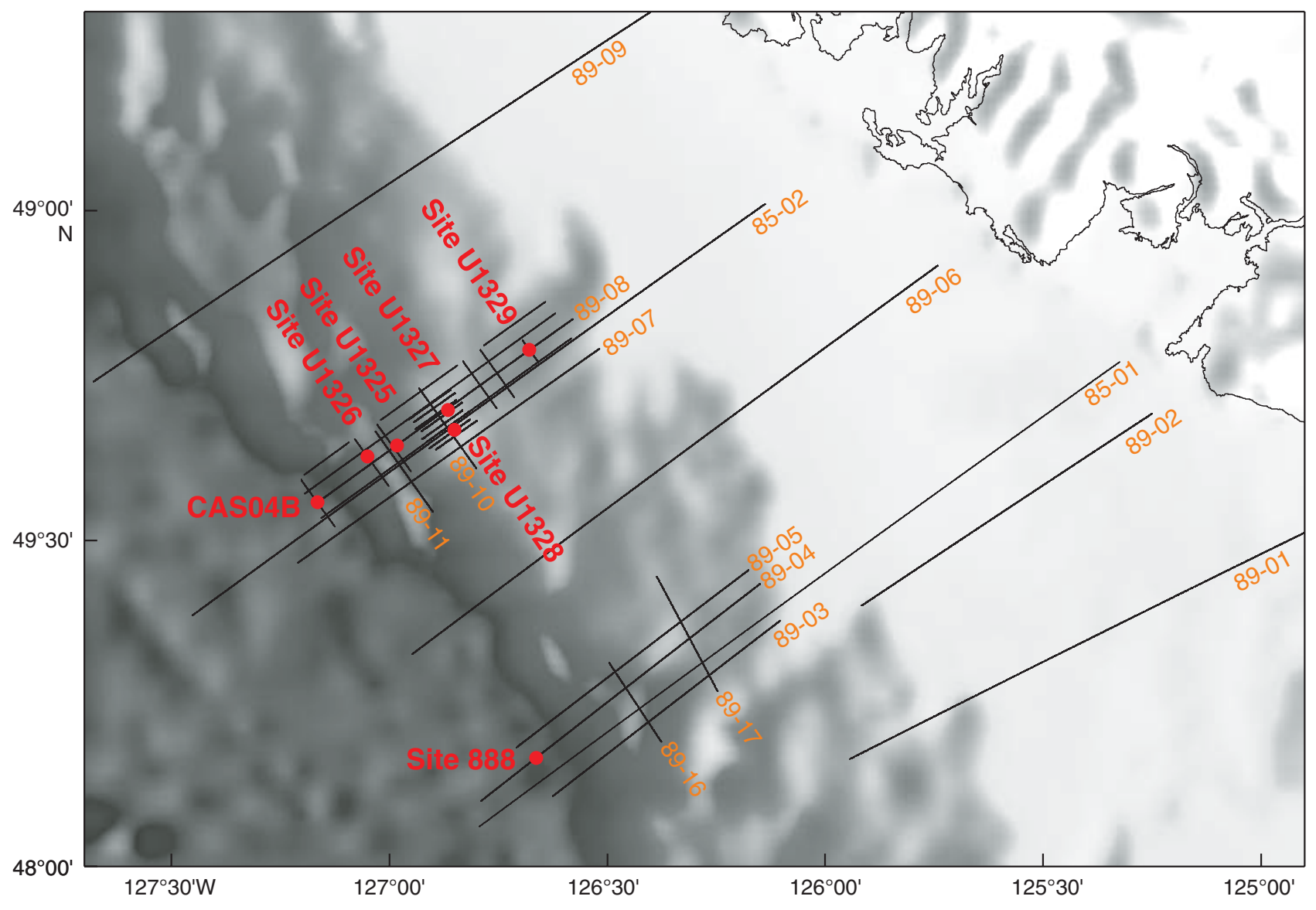


Figure F4. Marine gas hydrate cycle and fluid expulsion model (after Hyndman and Davis, 1992).

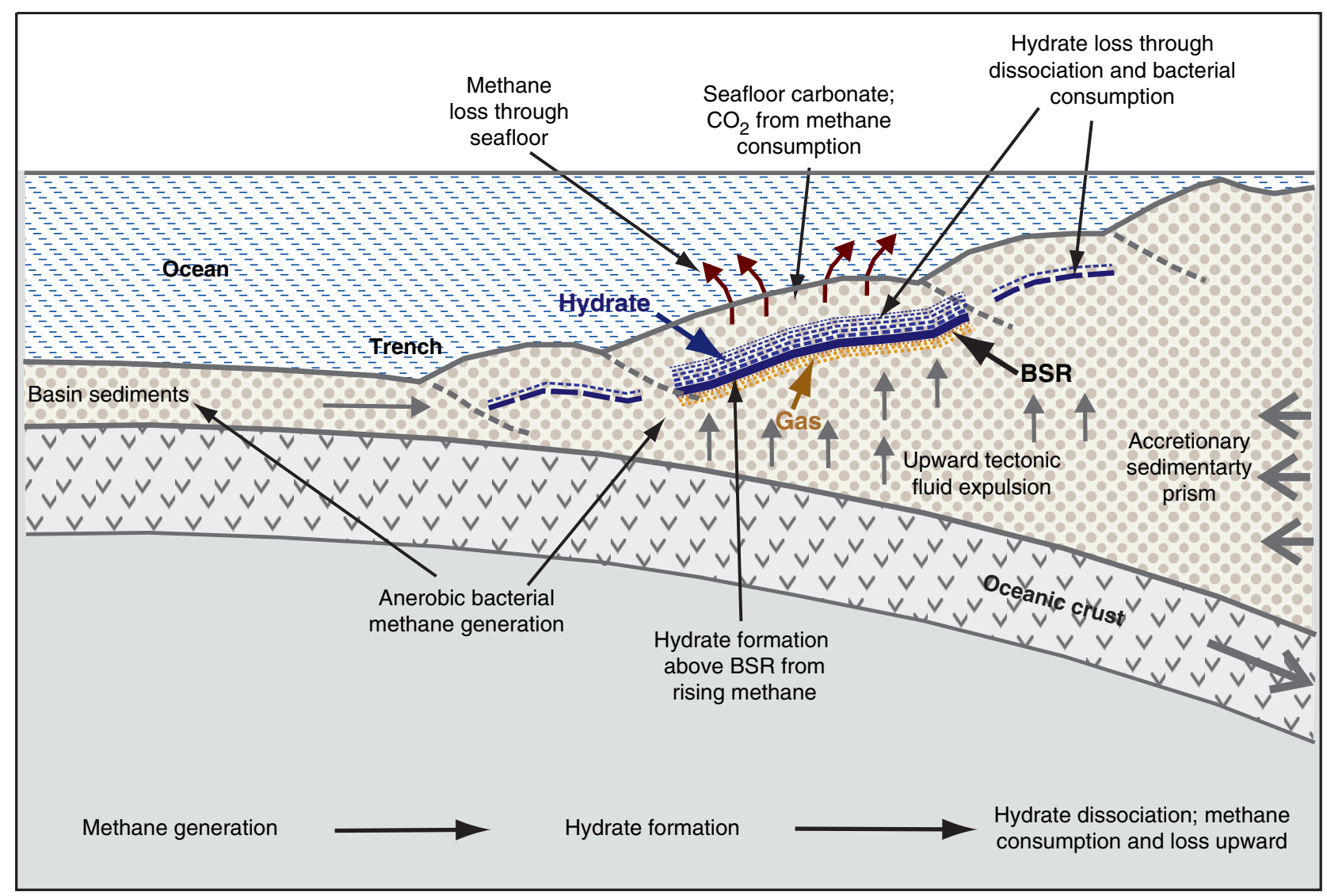


Figure F5. Heat probe measurements along regional seismic Line PGC9902_ODP2 (see Fig. F6) in comparison to bottom-simulating reflector (BSR)-derived values and other regional heat probe measurements in the vicinity of the seismic line.
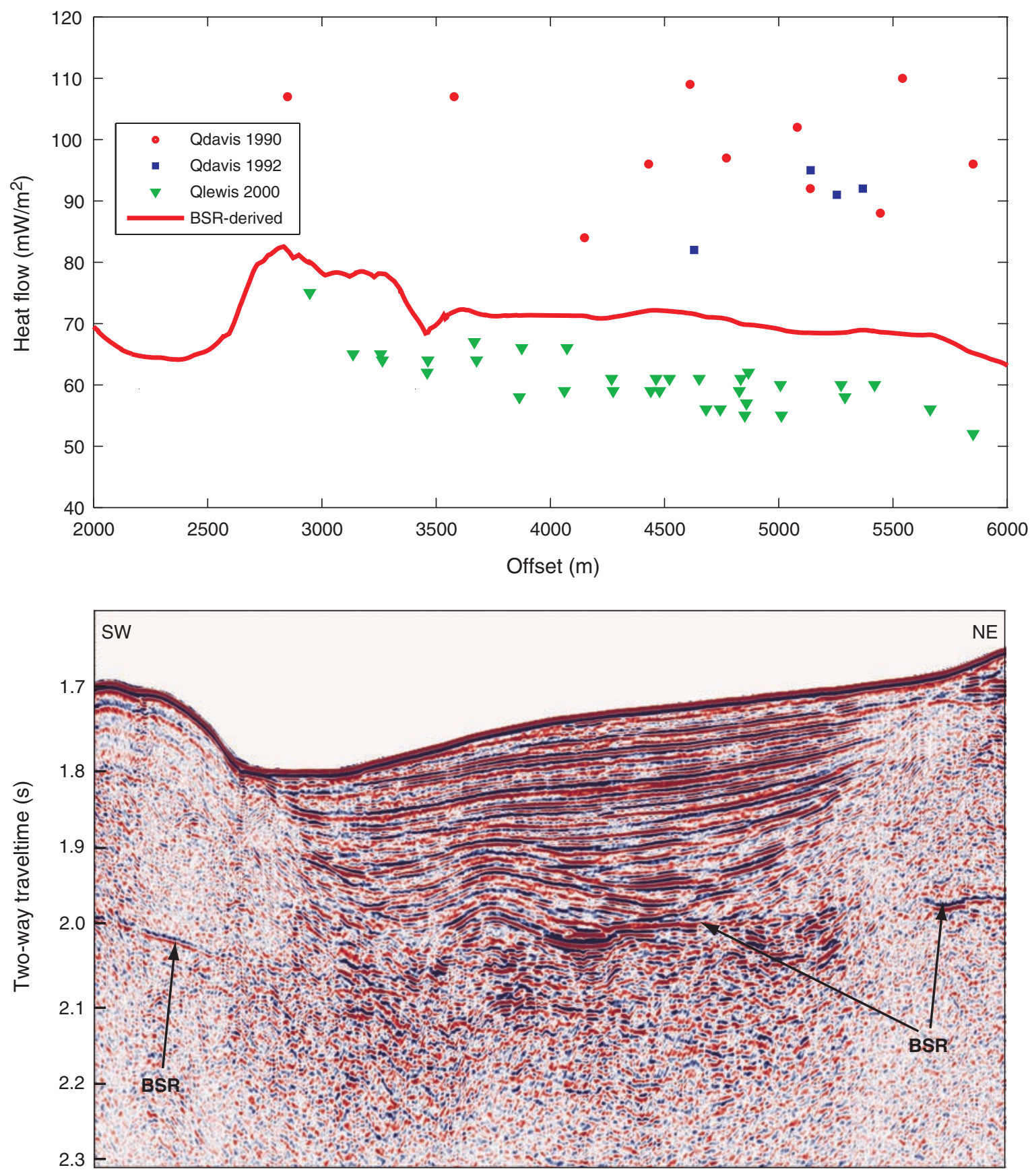
Figure F6. BSR-derived heat flow from regional pseudo 3-D single- and multichannel seismic lines around ODP Site 889/890 (after Riedel, 2001, and He et al., 2003).

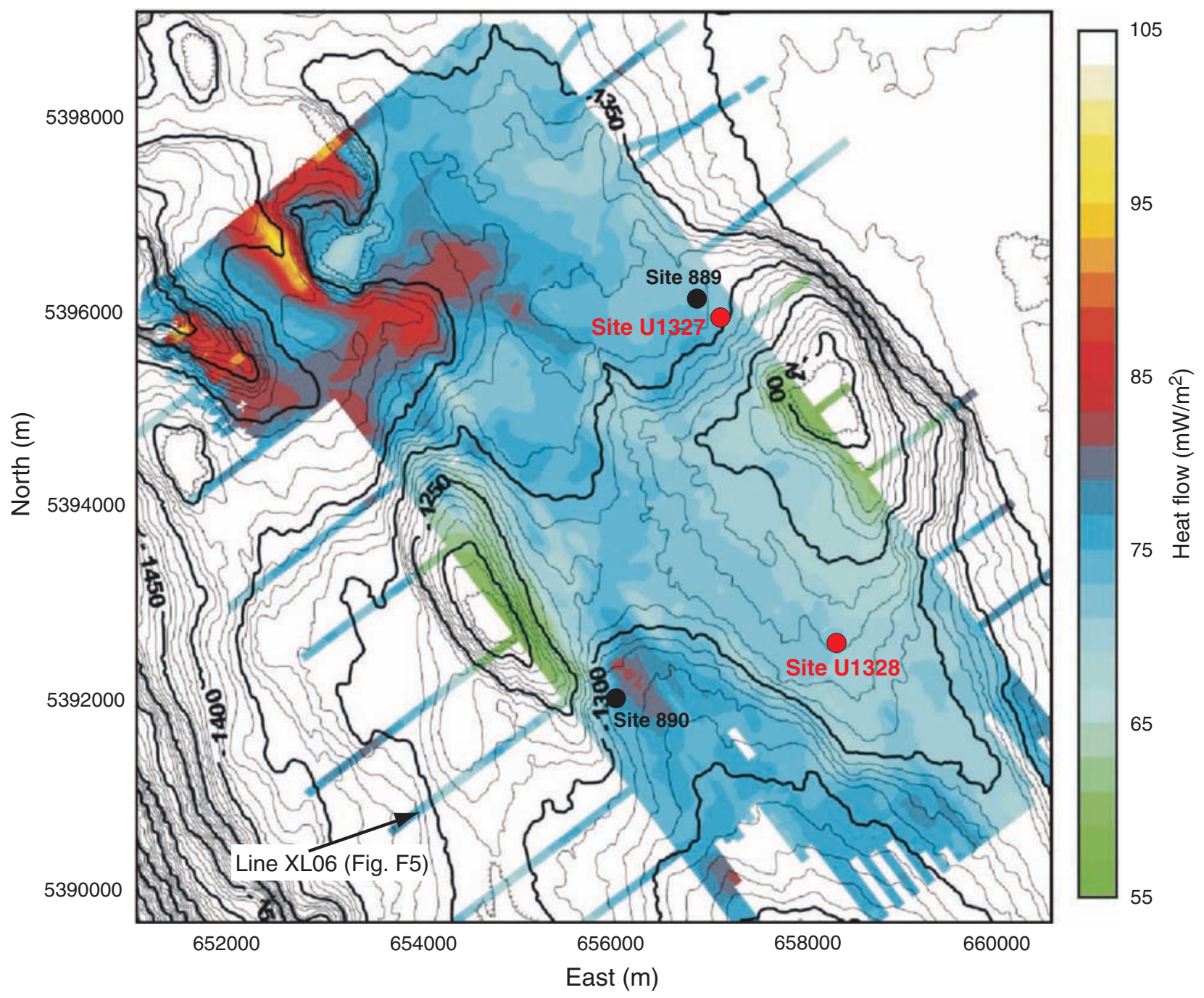


Figure F7. Pore water salinity of cores after gas hydrate dissociation from ODP Leg 146 Site 889/890 and deepsea reference Site 888 and Leg 204 Sites 1244, 1251, and 1252. Data from Leg 204 were reported as integer numbers only. Solid black line is a reference assuming that the main trend with depth at Site 889 represents the in situ salinity and only the minor deviations are due to gas hydrate dissociation. The blue and yellow lines are estimates of in situ pore fluid salinity from the method of Hyndman et al. (1999) using different Archie's relations coefficients (from Riedel et al., 2005). BSR = bottom-simulating reflector.

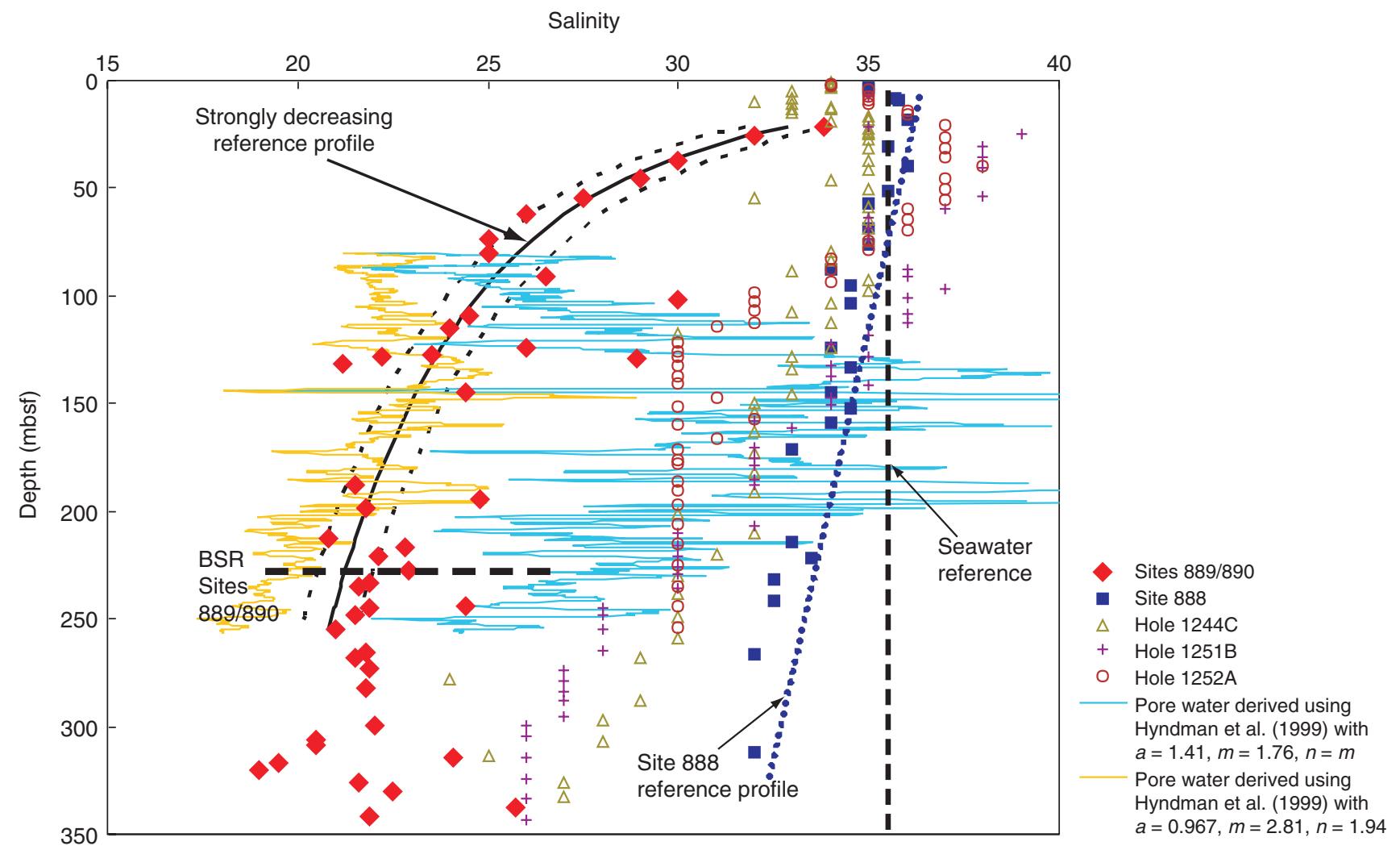


Figure F8. A. Core porosities from ODP Site 889/890, smoothed porosity profile after Athy's law (Athy, 1930), neutron porosity log at Site 889, and Yuan et al. (1996) porosity reference profile. B. Reference velocity profiles nd ODP Site 889/890 sonic log and seismic interval velocities. VSP = vertical seismic profile, sed. = sediment, re-proc. $=$ reprocessed. C. Gas hydrate concentrations from the Lee et al. (1993) equation reference. D. Gas hydrate concentrations from the Hyndman et al. (1993) reference with an empirical porosity-velocity function. E. Gas hydrate concentrations from the Jarrad et al. (1995) reference with a slightly revised empirical porosity-velocity function. F. Gas hydrate concentrations using the Yuan et al. (1996) reference profile for accreted sediments (from Riedel et al., 2005).

A

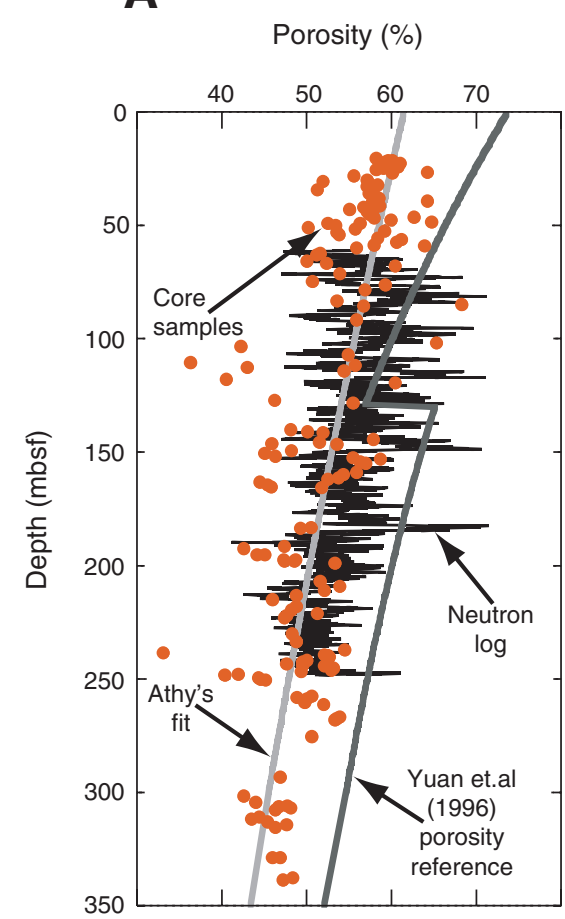

B

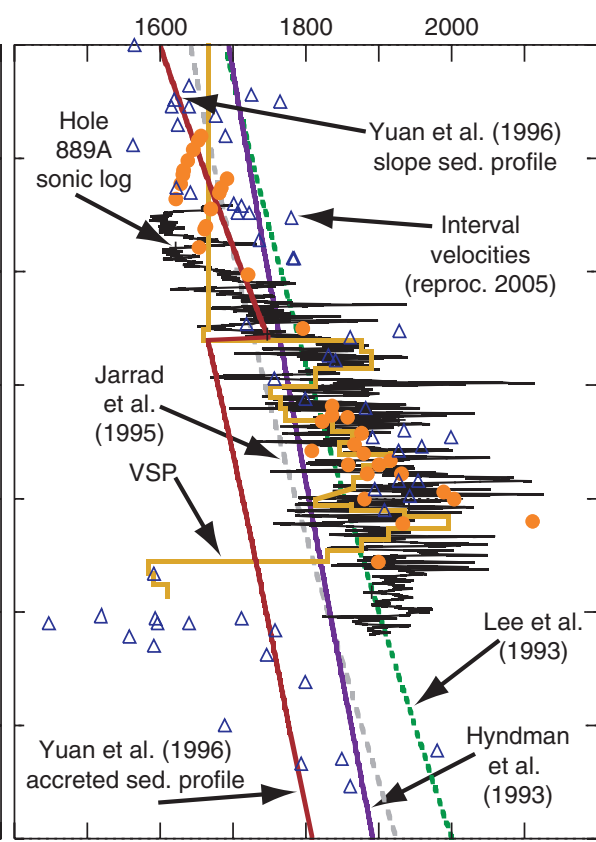

C

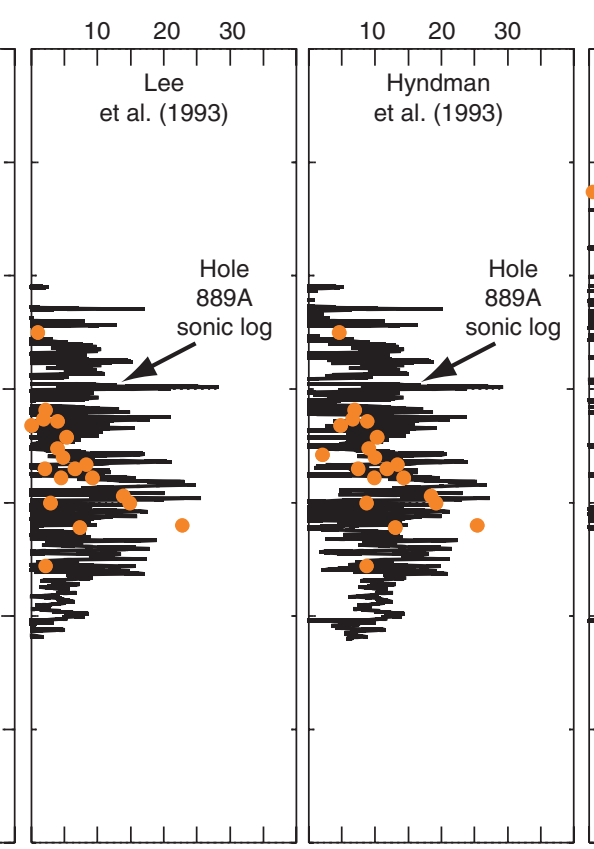

E

D tion (\% pore space)

$\mathbf{F}$

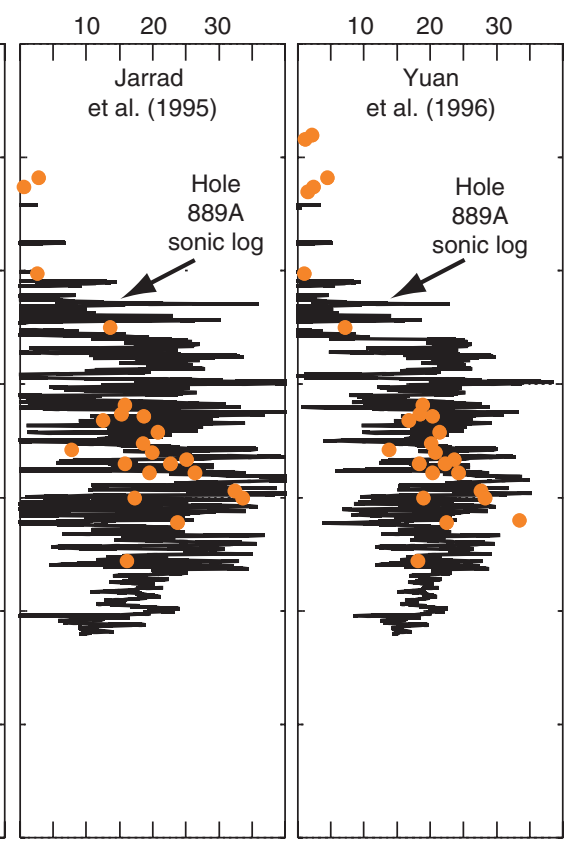

- Yuan et al. (1996) interval velocities 
Figure F9. A. location of vent field near ODP Site 889, additional seismically inferred vents from occurrence of blanking, and location of Cucumber Ridge, a large carbonate mound (He et al., 2003). B. Core locations around blank Zone 4. C. Core locations around Bullseye vent.

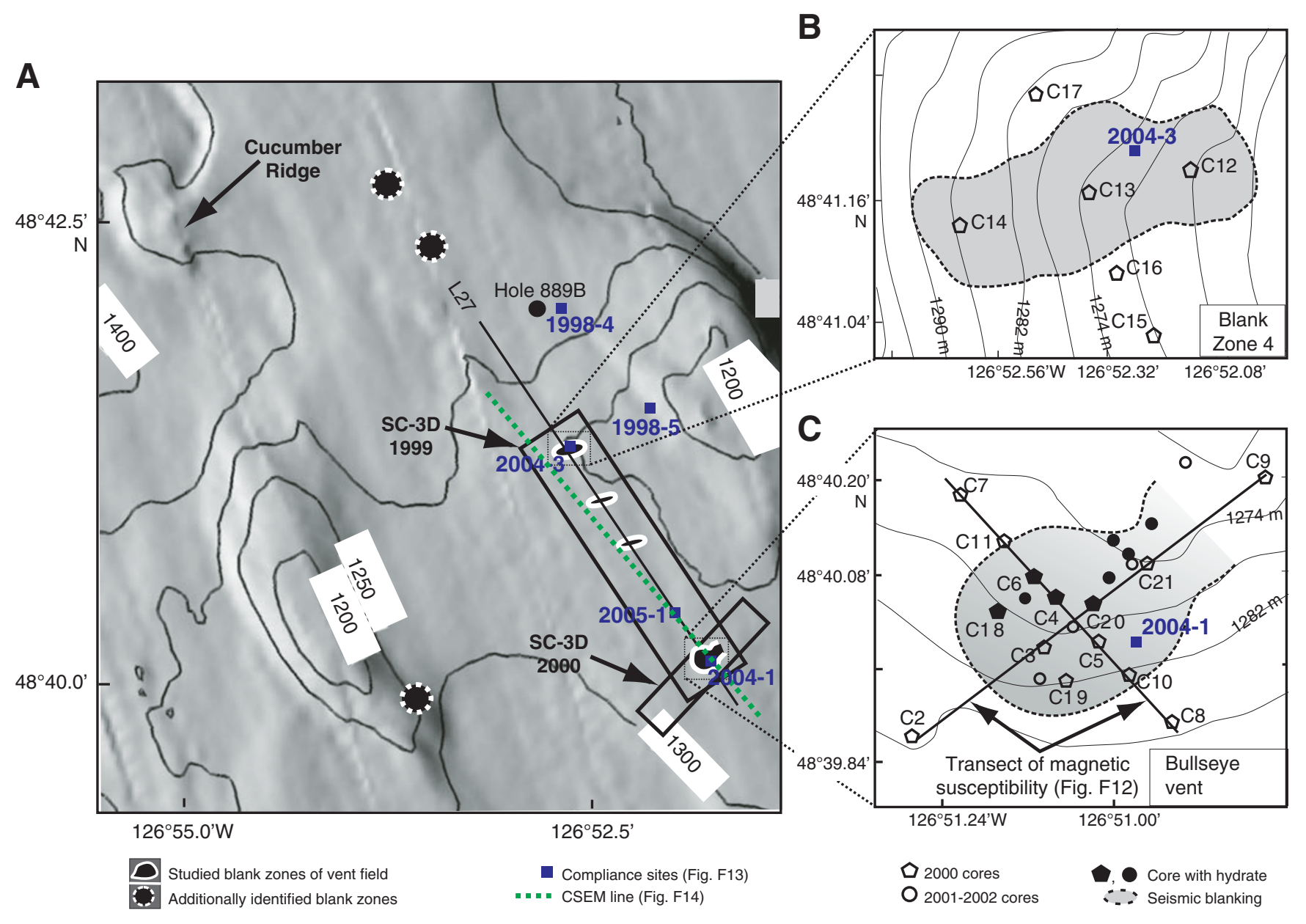


Figure F10. Seismic sections across cold vents near ODP Site 889. V.E. = vertical exaggeration, BZ = blank zone. A. $3.5 \mathrm{kHz}$ subbottom profiler data. B. Multichannel seismic (MCS) Inline 27 (stack) from 1999 pseudo-3-D seismic survey. A bottom-simulating reflector (BSR) is faintly visible beneath the vent field in the MCS data. Blanking is increased in the higher frequency subbottom profiler data (after Riedel et al., 2002). CDP = common depth point.
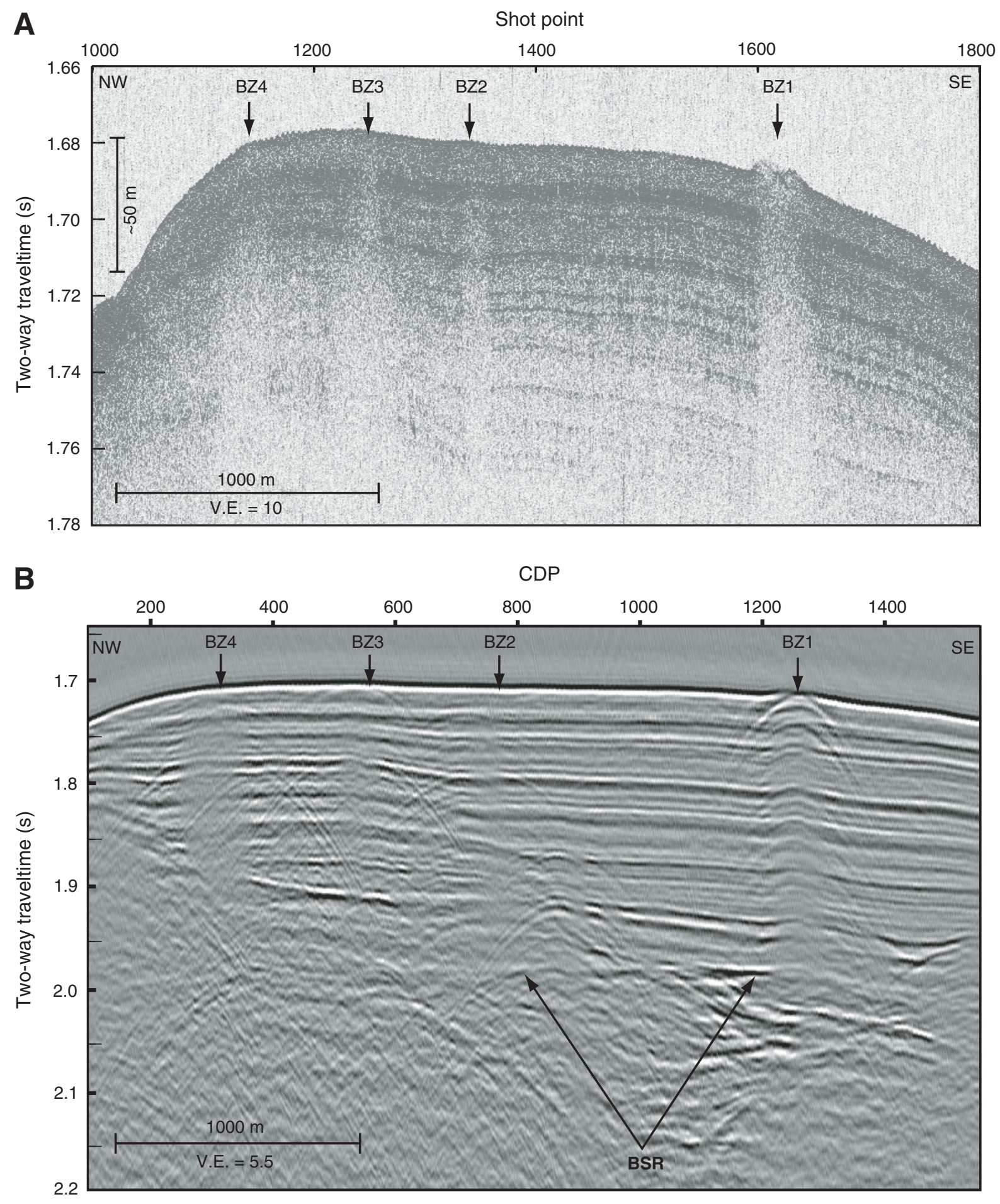
Figure F11. A. Time slice of instantaneous amplitude from single-channel seismic (SCS) 3-D grid at $1.752 \mathrm{~ms}$ two-way traveltime taken from 2000 grid over Bullseye vent. Diffraction rims are seen are bright colors (orange) surrounding the individual cold vents as a result of interference of diffractions with regular reflectors. B. Cross Line (XL) 75 from the 2000 SCS data showing hydrate cap reflector at Bullseye vent. Note reduced seismic amplitudes below center of the vent. Hydrate was recovered in piston Core C-6 at a depth of $\sim 6.5 \mathrm{~m}$ below seafloor (after Riedel et al., 2002).
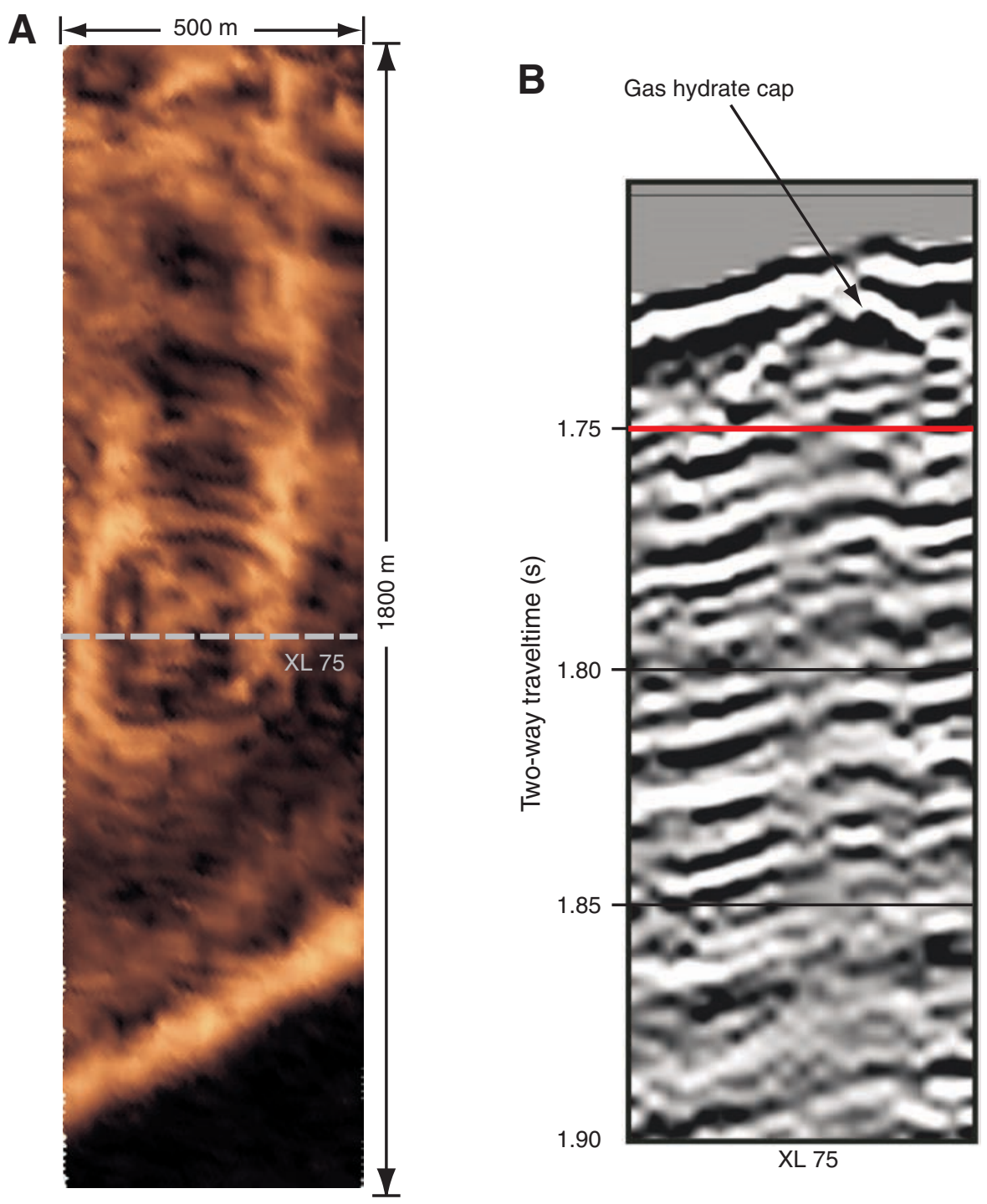
Figure F12. (A) Magnetic susceptibility along Transect 1 and (B) Transect 2 (10 cm sampling interval). High magnetic susceptibility values mostly range from 2500 to $3000 \times 10^{-6}$ SI (darker shaded area), whereas low magnetic susceptibility values mostly range from $50 \times 10^{-6}$ to $500 \times 10^{-6}$ SI (lighter shaded area). Patterned areas represent sections that contained massive gas hydrate. Depth ranges with no available data are shown in white (after Novosel et al., 2005).

A Magnetic susceptibility $\left(10^{-6} \mathrm{SI}\right)$
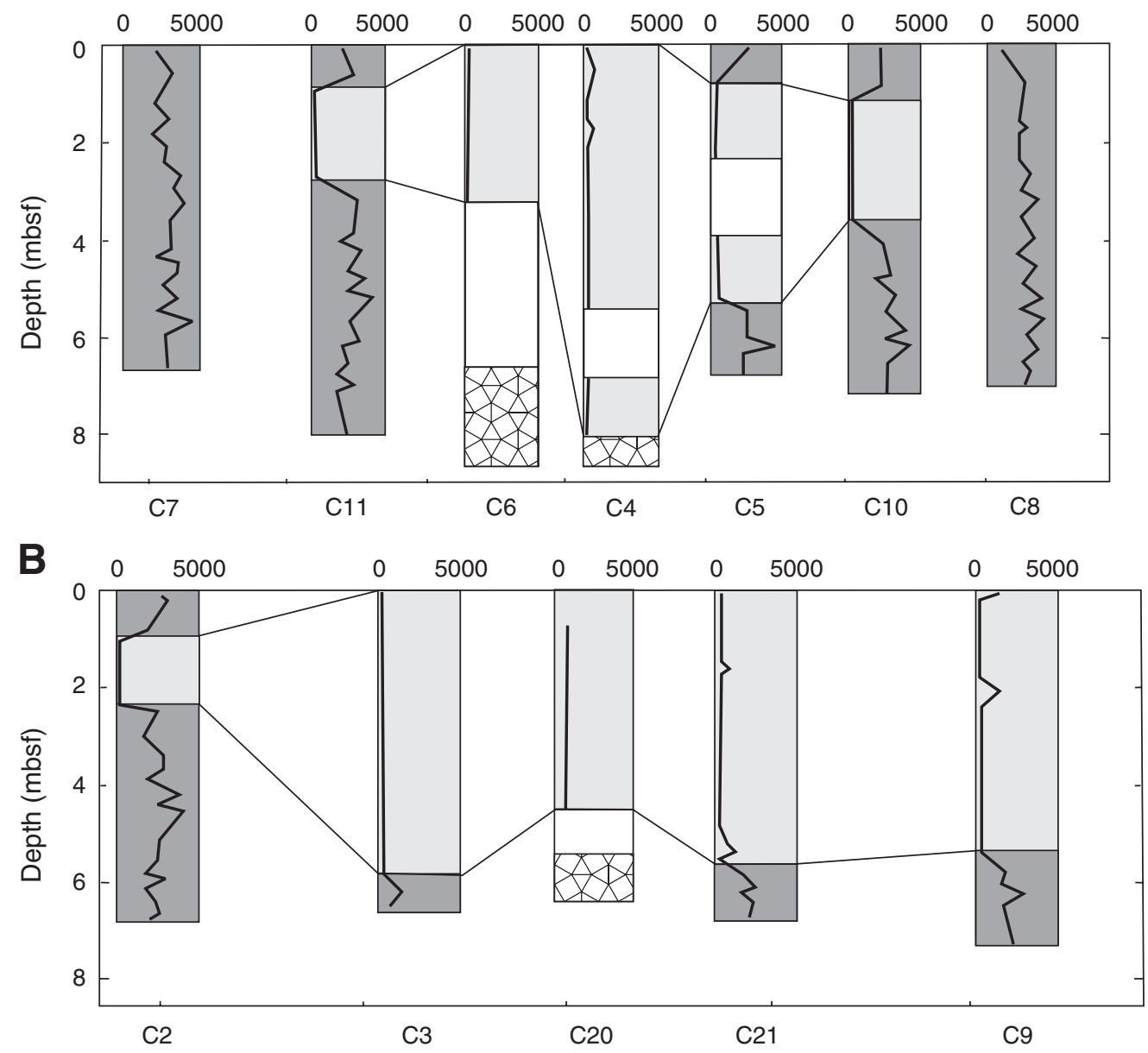
Figure F13. Normalized compliance, coherence, and velocity profiles. The regional trend velocity-depth model and calculated compliance with frequency are shown by the blue dotted lines and 1998 best-fit model of regional gas hydrate above the BSR by the solid red lines. The cold vent model is shown by the dashed line. The 3-D finite difference vent model compliance results are indicated by red stars (after Willoughby et al., 2005).

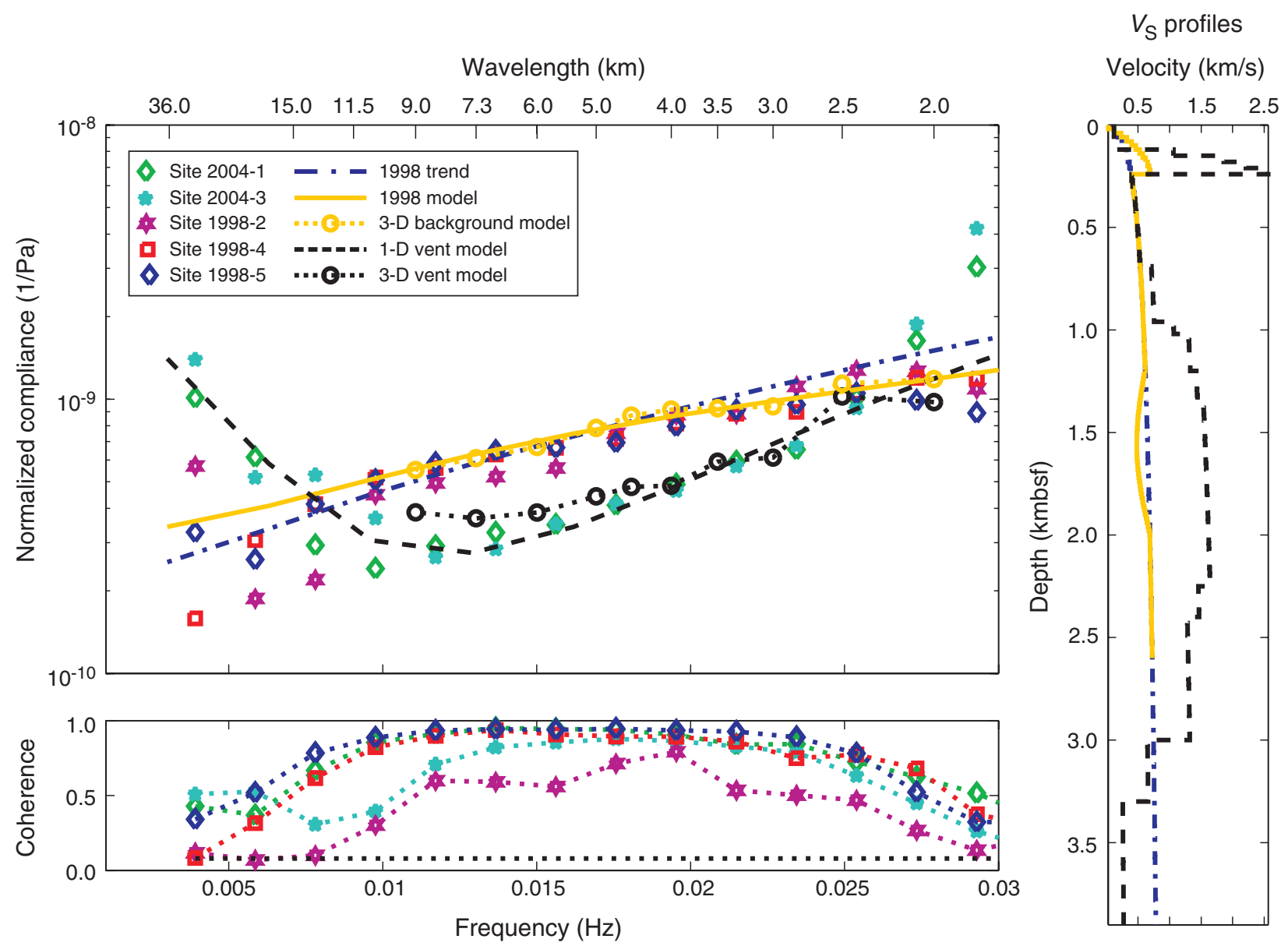


Figure F14. A. CSEM resistivities (background values $=\sim 1.1-1.5 \Omega \mathrm{m}$ ) showing local high-resistivity anomalies $>5 \Omega \mathrm{m}$ spatially correlated with blank Zones 1-4. B. Seismic line from 1999 single-channel seismic 3-D survey (coincident to Inline 27 shown in Fig. F10) on the same horizontal scale (after Schwalenberg et al., 2005). $\mathrm{BSR}=$ bottom-simulating reflector, $\mathrm{BZ}=$ blank zone.
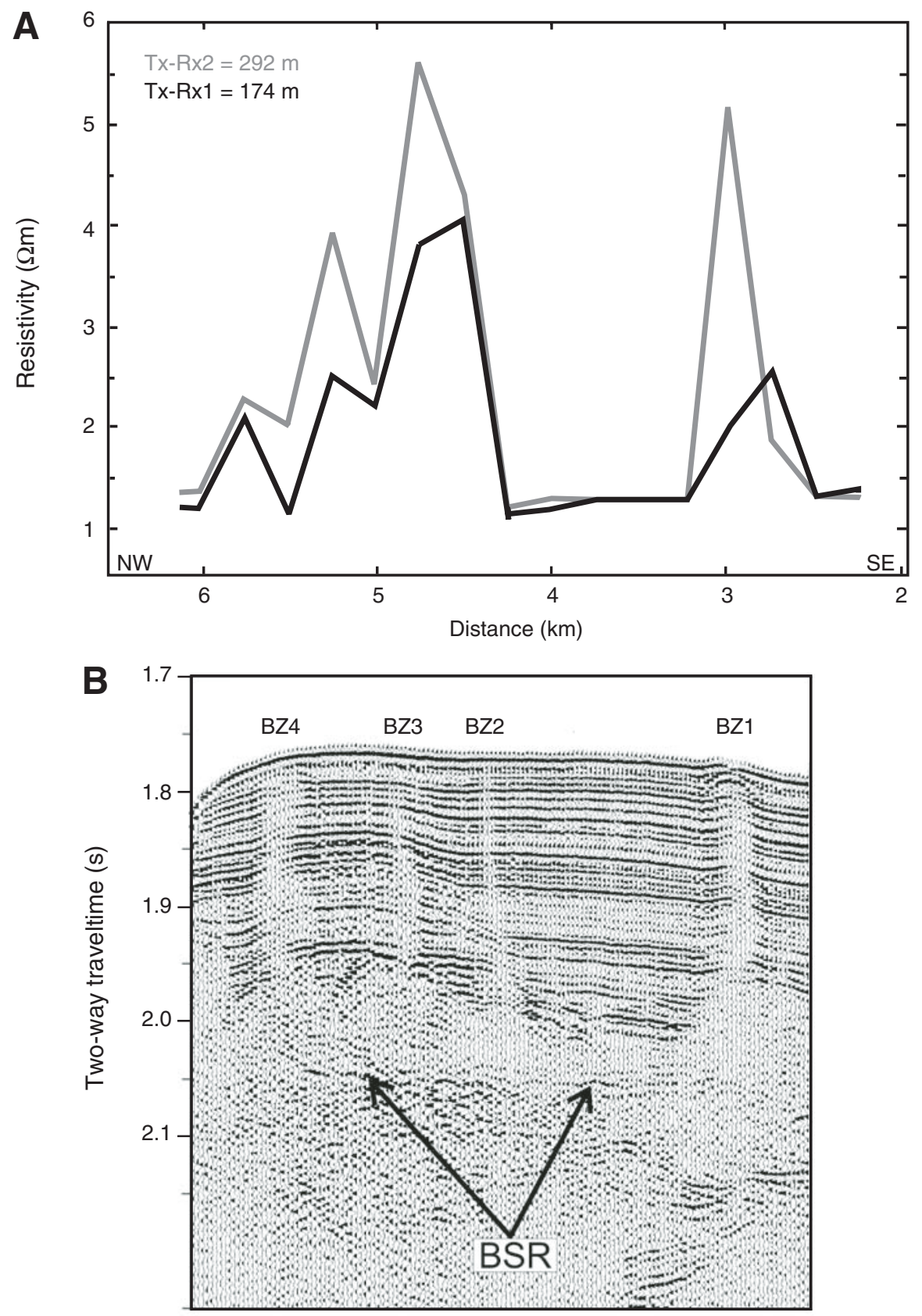